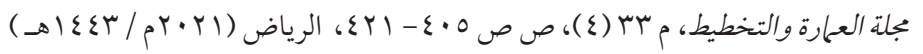

doi:10.33948/JAP-KSU-33-4-5

\title{
المدينة الذكية: من قوة الحداثة إلى القوة الذكية
}

\author{
عبير حسام الدين اللحام \\ أستاذ مشارك، كلية التصاميم، جامعة الإمام عبد الرحمن بن فيصل ، الدمام، السعودية \\ drallahham@hotmail.com \\ قدم للنشر في ع/r/r/r ع ا هـ ؛ـ وقبل للنشر في / / / ع ع ا هـ.
}

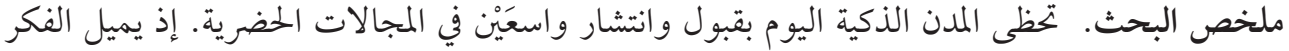

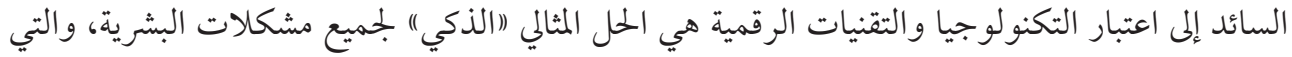

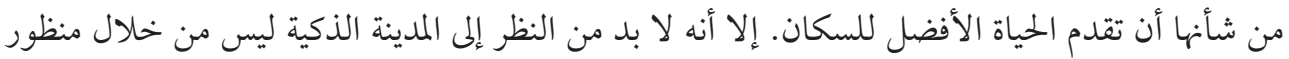

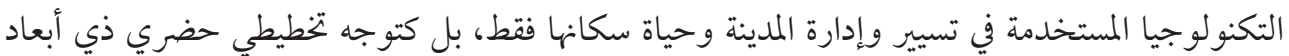

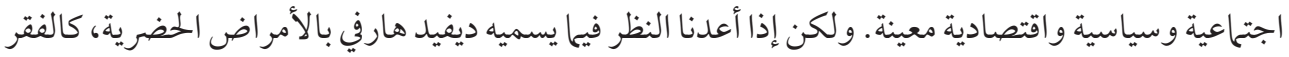

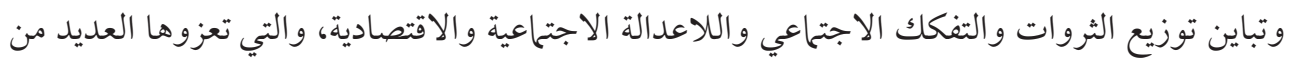

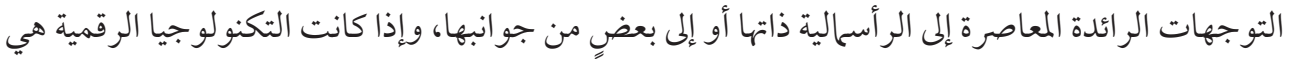

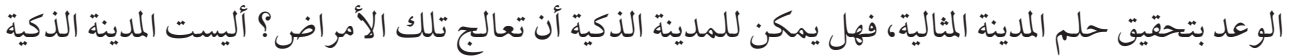

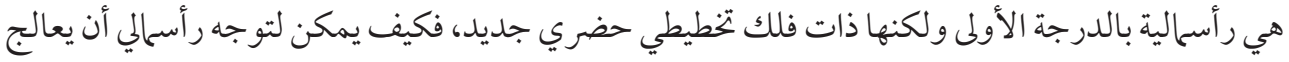

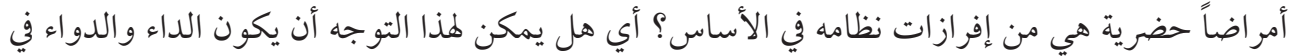

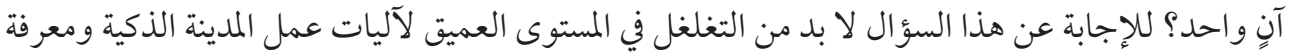

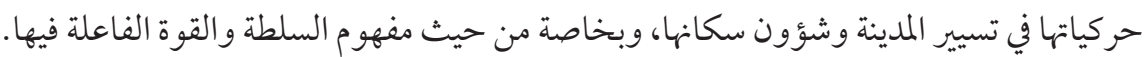

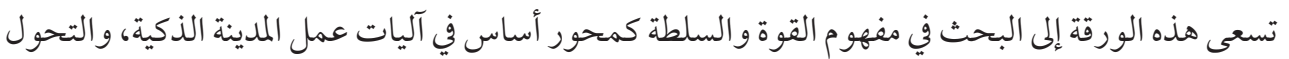

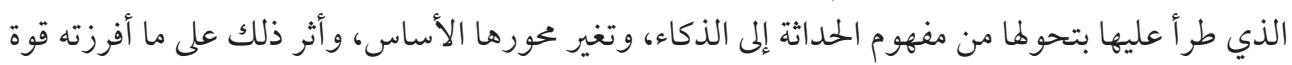

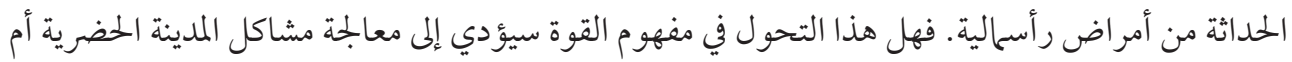

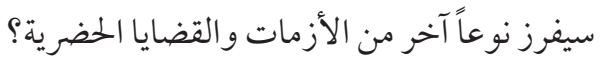

الكلمات المفتاحية: المدينة الذكية، ذكاء القوة، التوزيع المناطقي، الرأسمالية، العام والخاص. 
والمــدن المعـززة (Augmented cities) وغيرهـا (الجــار

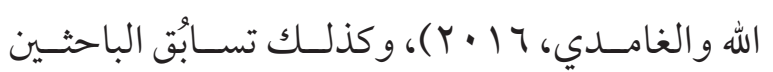

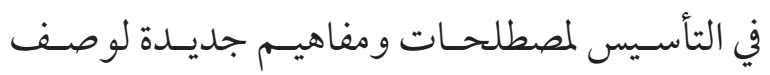

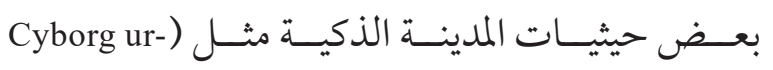
Pasquale و التـي أوجدهـ (banism

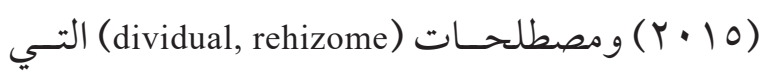

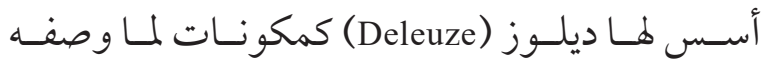
بمجتمــع السـيطرة (society of control) في المدينـة

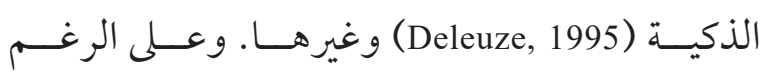
مــن هـــا التشـــب في التعريفــات و المصطلحـــات

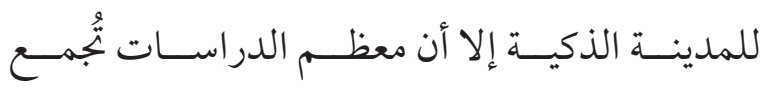

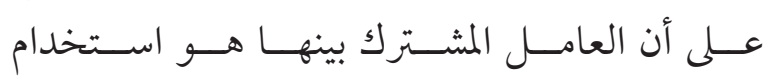
التكنولوجيــا لتســير شـؤون المدينــة وســــانها

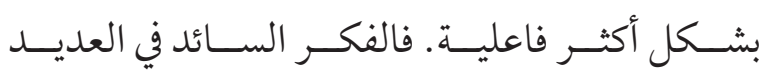

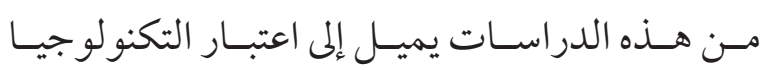

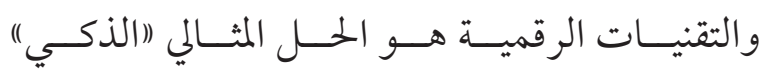

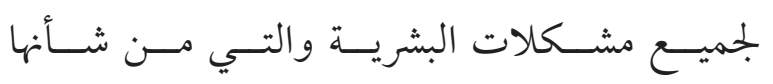

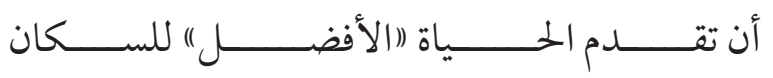
(Husar et.al., 2017، Vanola, 2014)

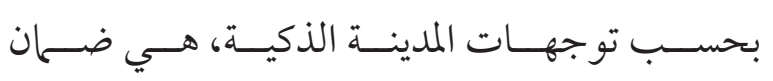
العيـش الرغيـــ أو هـي الحـل لتحقيـق المدينـة المثاليـة

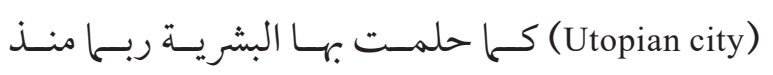

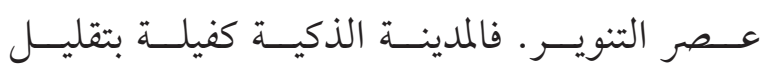

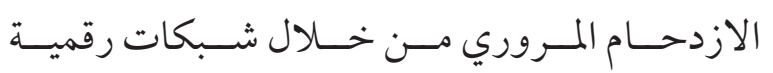

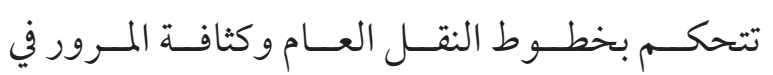

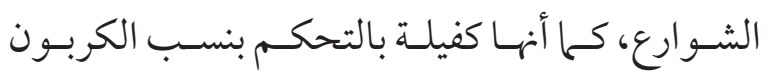

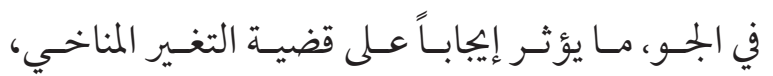

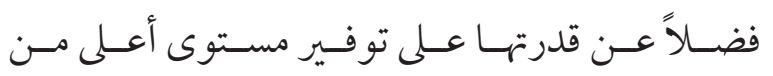

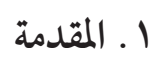

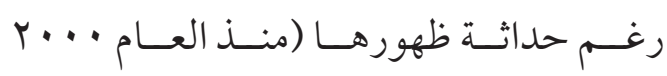

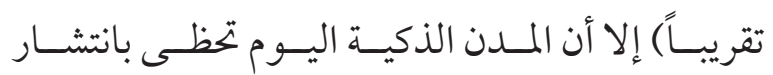

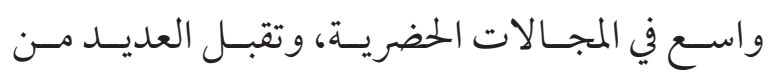

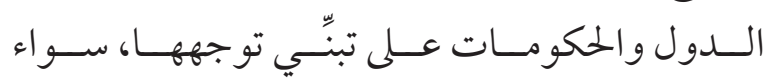

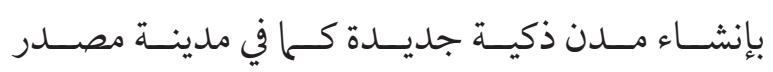

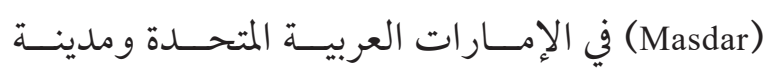

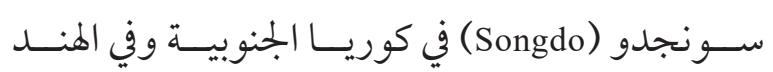

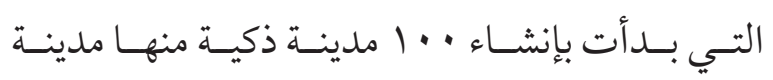

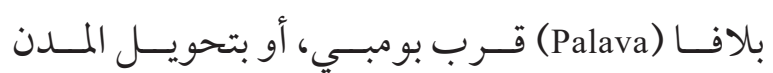

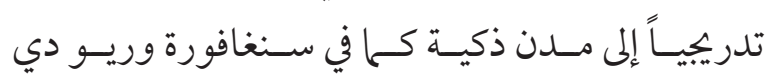

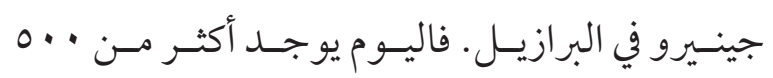

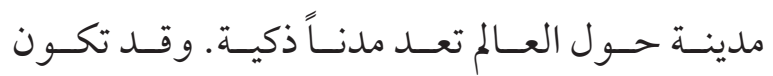

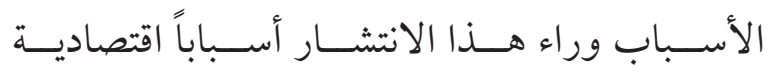

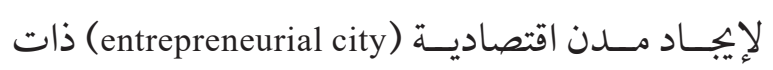

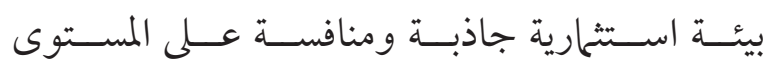
العالمي (Hollands, 2008) أو بيئيـة، أو ربــا سياسـية

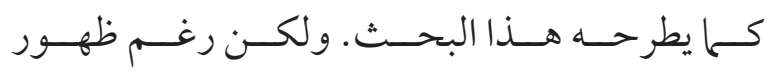
العديــد مـن الدر اســات ذات التخصصــات المختلفــة

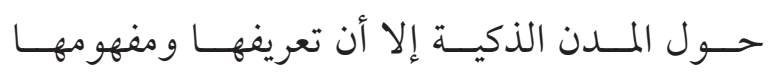

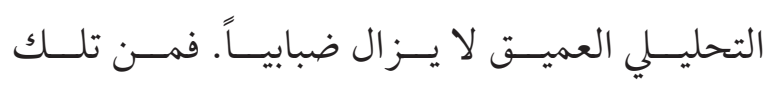

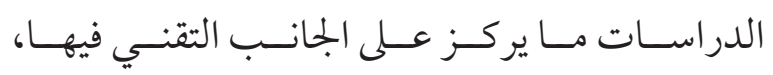

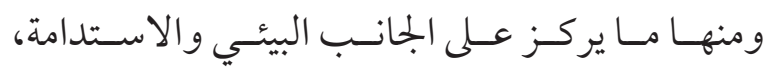

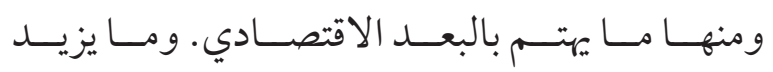

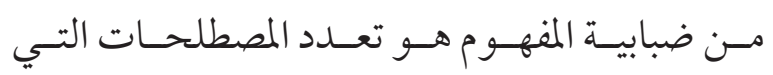
ظهـرت لو صـف تلـك المـدن كالمـدن الذكيـة (Smart Digital) والمـدن الرقميـة (cities)، (Intelligent cities (cities )، والمـدن دائمسة الوجـود (Ubiquitous cities)، 
ســانها وقضايــا الخصو صيــة وحقـــوق الإنســان المتعلقــة بذلـك (www.privacyinternational.org)، إلا أن معظــم تلــك الدراســات لم تتمكــن، ربــــا

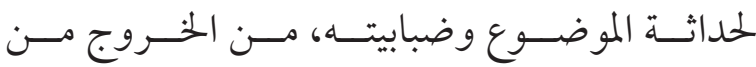
هـذا الإطـار في النظــر للمدينـة الذكيـة، فظهـرت في معظمهــا كدر اسـات ليســت ذات تحليـلات مقنعـة، بـل ربــا مثبتـة (affirmative) لمفهـو م المدينـة الذكيـة.

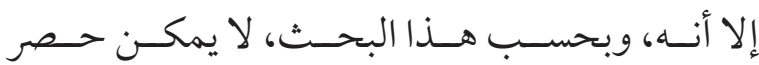

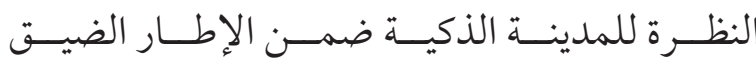
للتكنولو جيـا و المعلو مـات الرقميـة، بــل لا بــد مــن

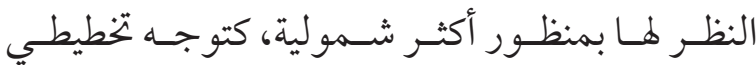
حــضري ذي أبعـاد اجتتاعيــة وسياسـية و اقتصاديــة

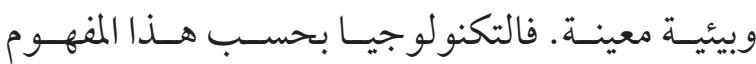

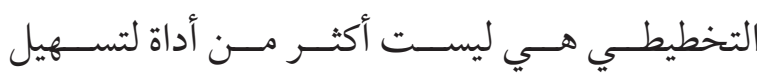

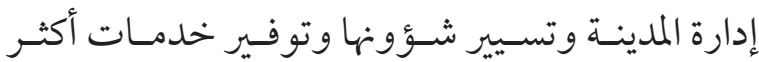

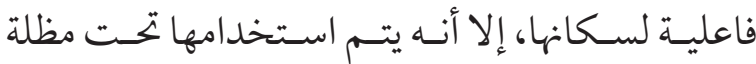

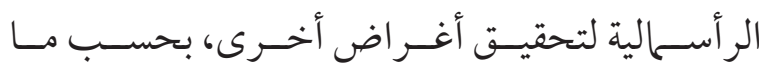

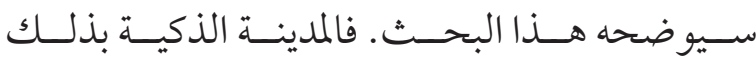

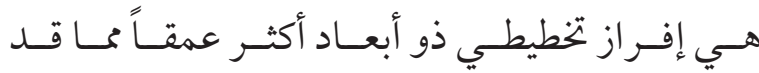

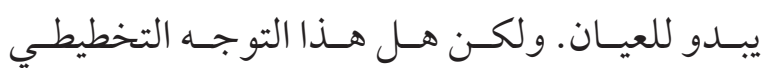

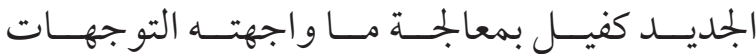

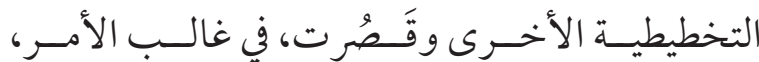

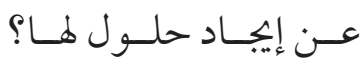

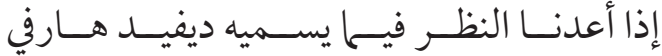

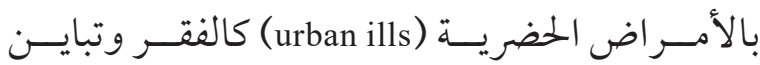
توزيــع الثـــورات و التفـكك الاجتهاعسي واللاعدالـة

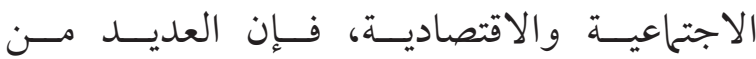

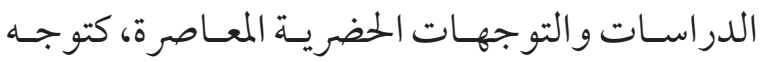

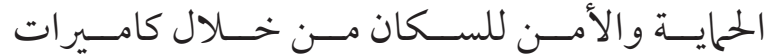
المراقبـة (CCTV) المنتـشرة في جميـع الفر اغـات العامـة

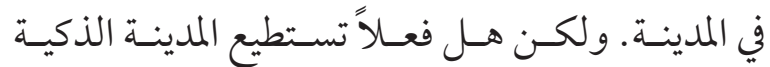

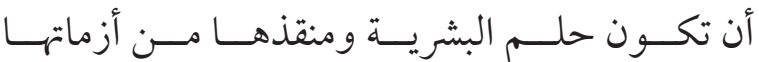

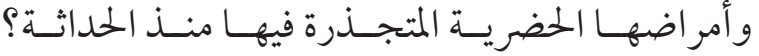

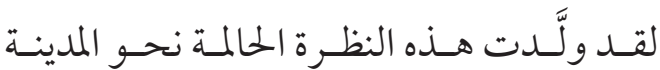

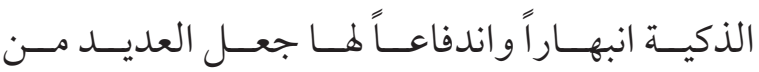

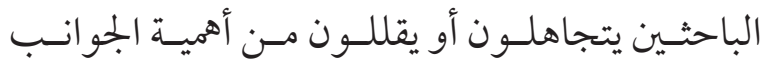

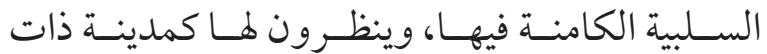
تكنولو جيـا ومعلو مـات رقميـة ذكيـة، تحكمهـــا نظــم حوكمـة رقميـة (e-governance) غـــر أيديولوجيـة. أي أنهـا مدينـة ليسـت ذات أجنـدة سياسـية. فظهرت

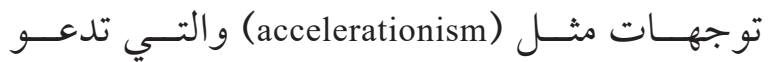

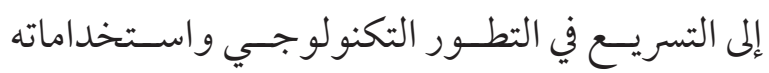
في هــا المجهـال. ولكــن نفـى بعـض الباحثـين هـذهـ النظــرة، إذ يعتــبر سادوســكي (Sadowski, 2016) وجرينفيلـد (Greenfield, 2013) أن المدينــة الذكيــة

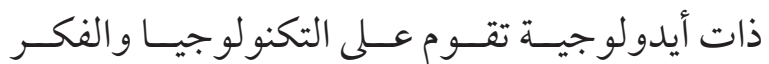

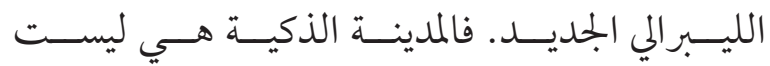

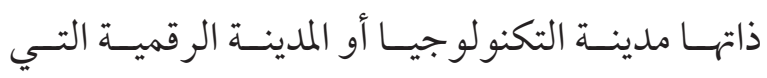
تقـــوم عــلى التكنولو جيــا الرقميــة فحســـب، بــل هـــي مدينــة تســتخدم التكنولو جيــا تحــــت مظلـــة أيديولو جيــة وسياسـية. ولكــن عـلى الرغــم مــن

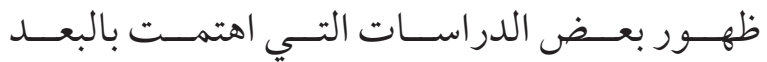
الاجتماعسي والسـياسي للمدينــة الذكيــة و التــي

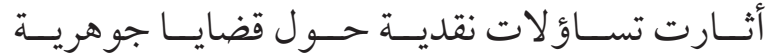
كديمقر اطيــة المعلومهـات التــي تقـــوم الشــبكات التكنولو جيـة بتجميعهــا في المدينـة الذكيـة عـن حيـاة 
وضرورتهـا في الحيـاة اليوميـة، بـل يركـز عـلى المدينـة

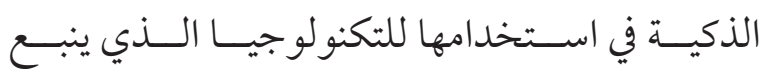

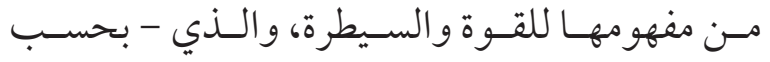

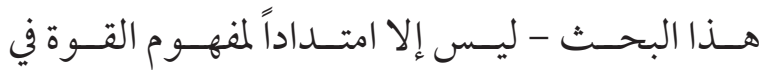

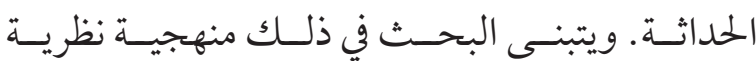

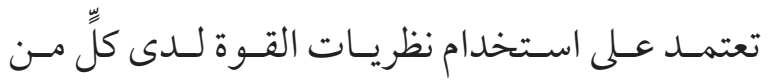

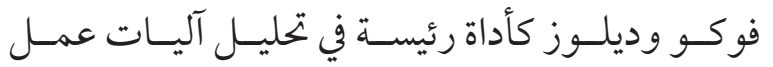

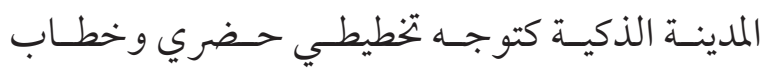

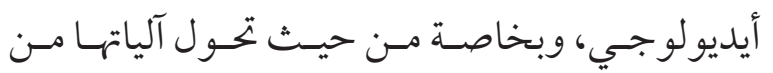

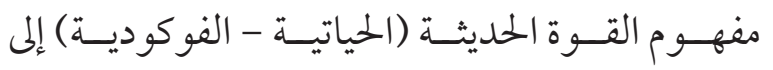

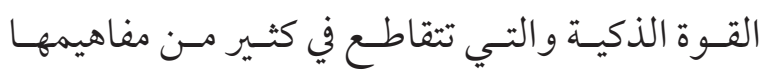

$$
\text { مــع القــوة (الديلوزيـة) ). }
$$

\section{r. القوة في المفهوم الحداثي: القوة الحياتية}

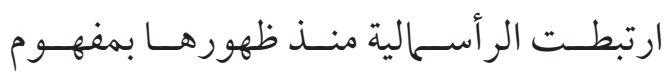

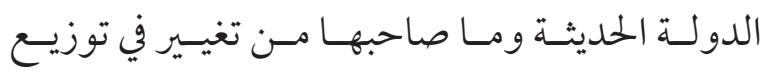

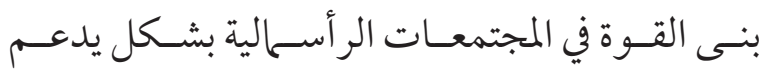

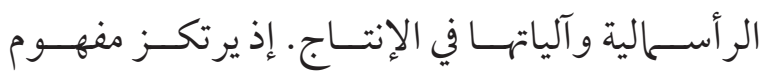

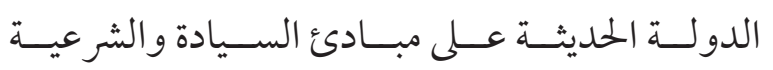

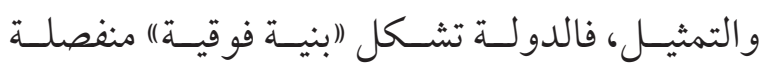

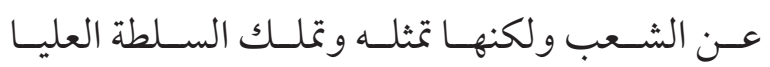

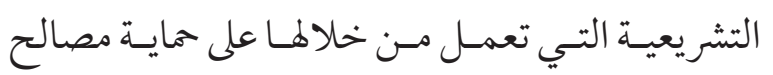

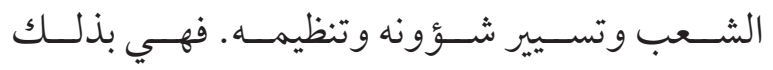

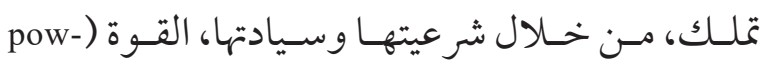

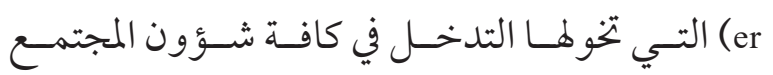

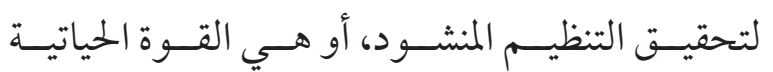
(bio-power) القـوة للسـيطرة عـلى الشـعب وإخضاعـهـ مـن خـالال
العدالـة الاجتماعيـة الحضريـة (Urban social justice)

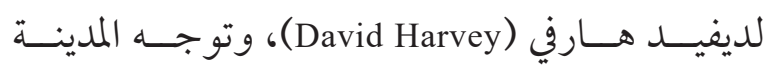

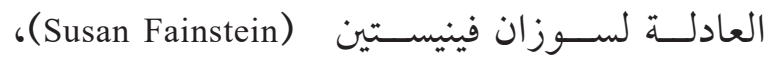

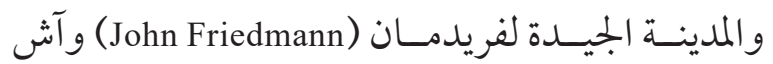

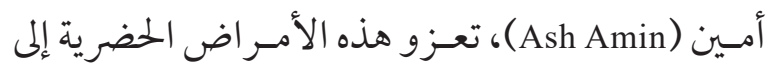

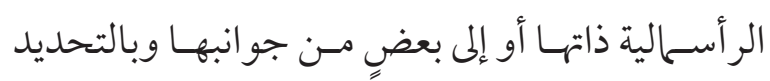

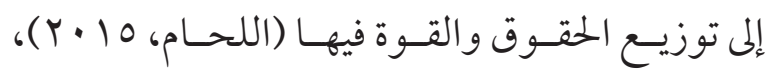

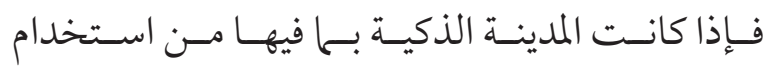

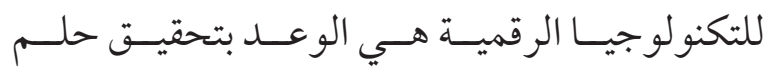

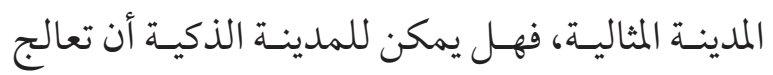

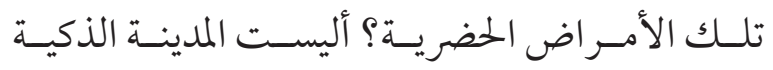

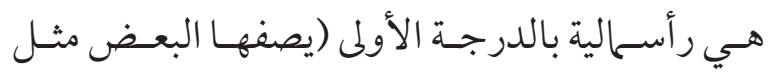

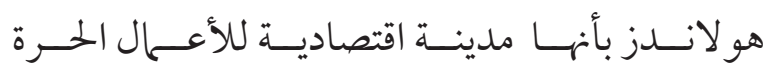
ولكنهـ (entrepreneurial city (Hollands, 2008)) ذات فلـك تخطيطي حـضري جديــ، فكيـف يمكـن

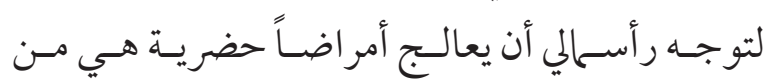

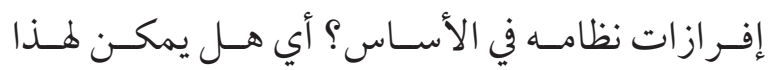

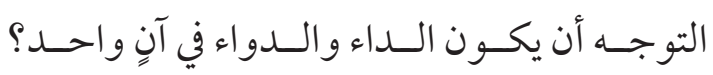
للإججابـة عـن هــا السـؤال يسـى البحـث إلى التغلغـل في المسـتوى العميـق و الأيديولوجسي لآليات

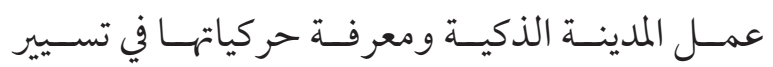

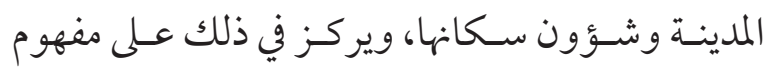

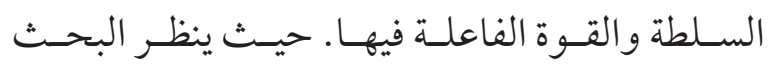
للمدينــة الذكيــة كخطــاب (discourse) ذي إطــار

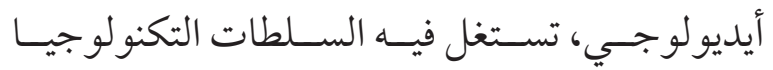

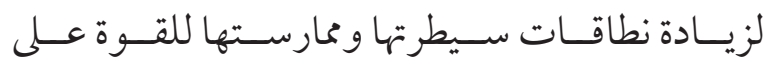
الأفــرادو المجمــوع، فهـي بذلــك مدينــة (الســيطرة

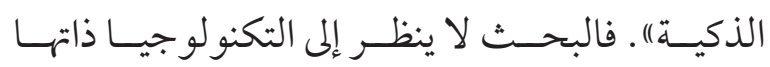


و الأســـواق) إلى ملكيــات عامــة، تملكهـــا وتسـيطر

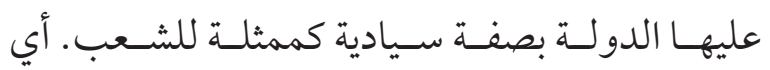

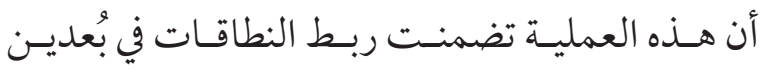

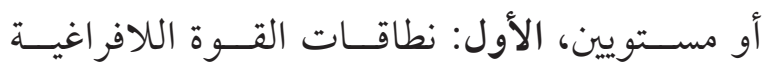
(bio-power)

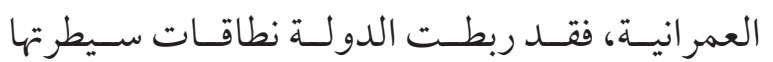
بالتوزيــع المناطقـــ (power territories / scopes)

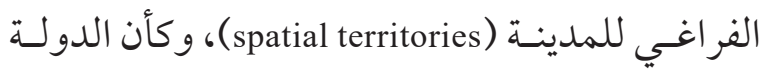

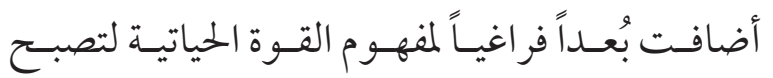

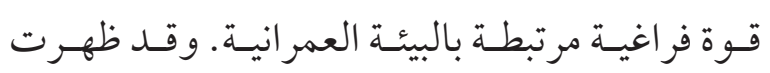

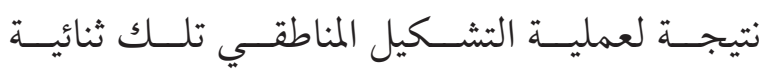

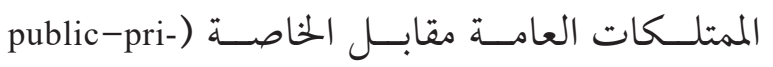

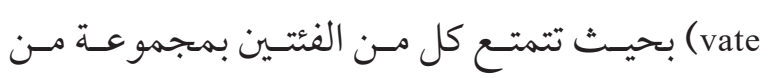

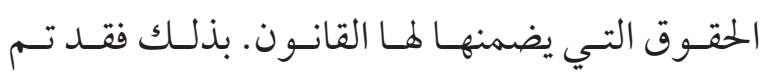

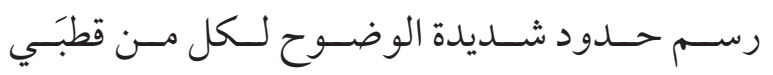

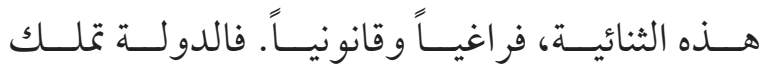

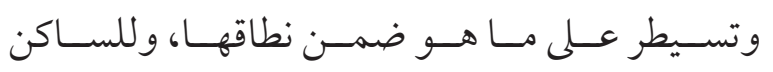

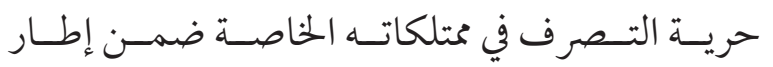

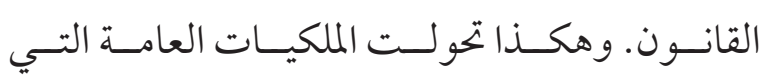

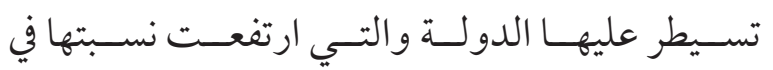

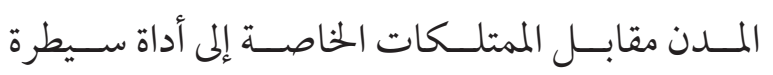

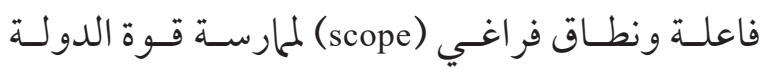

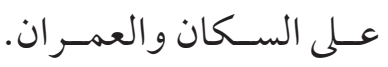

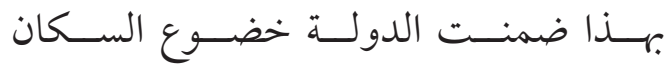

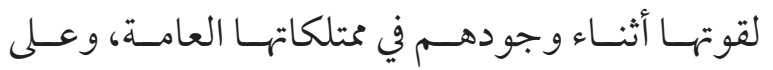

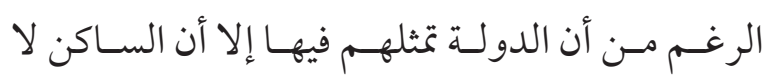

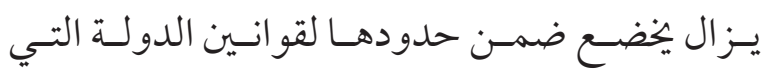

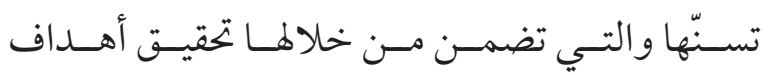

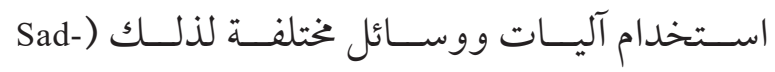
owski \& Pasquale, 2015

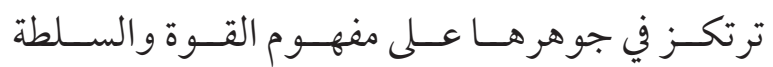

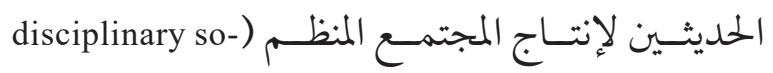

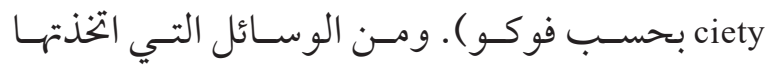

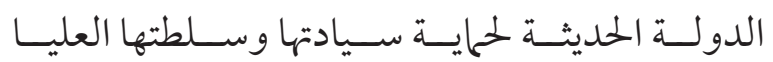

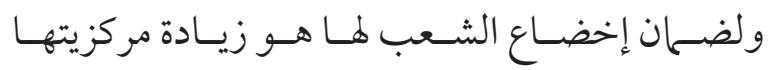

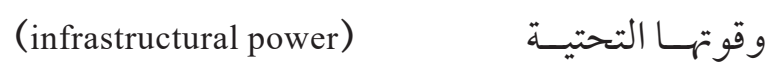

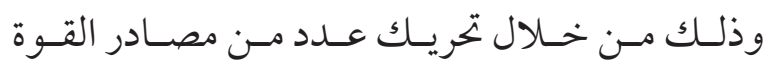

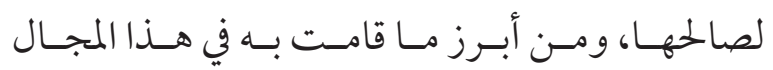

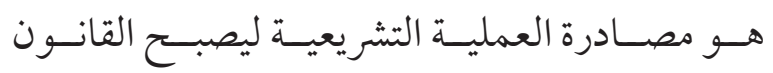

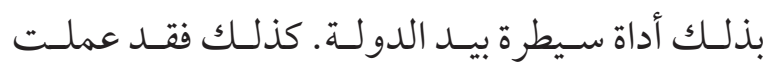

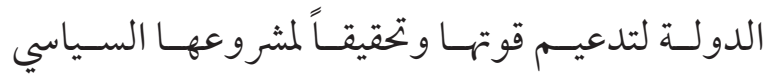

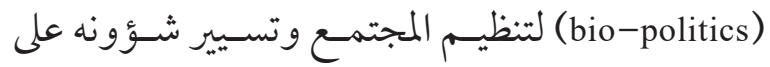
توسـيع دوائـر سـيطر تها بطــرق متعـددة مـن أهمهـا:

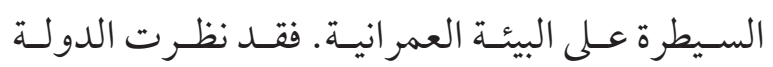

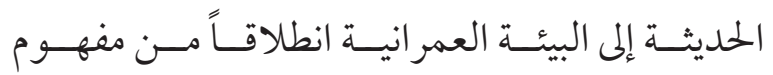

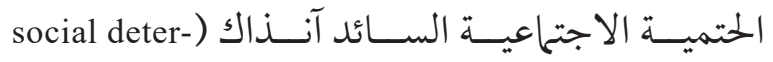

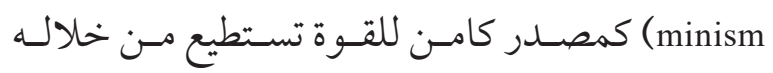

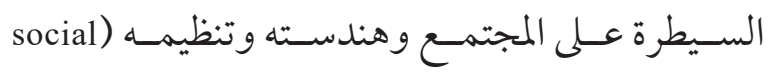

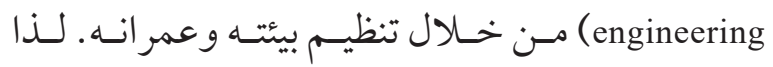

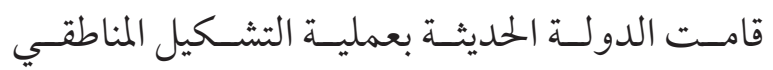

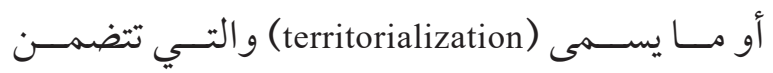

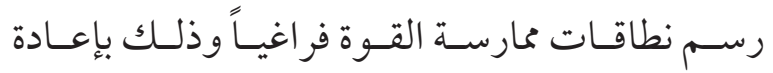

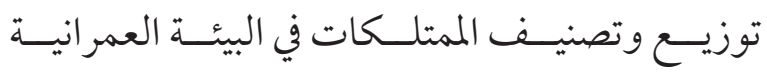

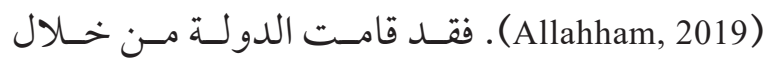

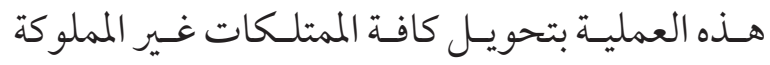

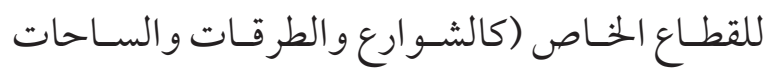




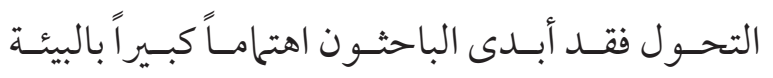

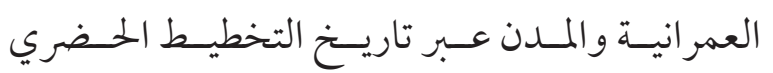

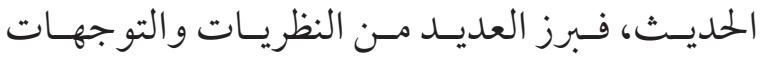

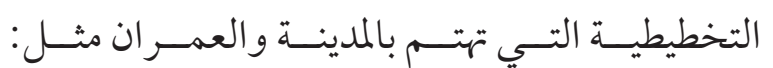

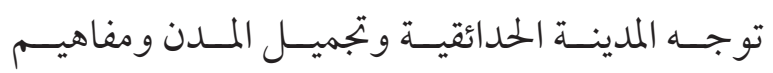

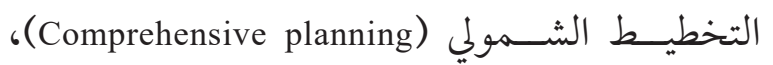

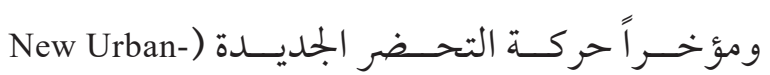

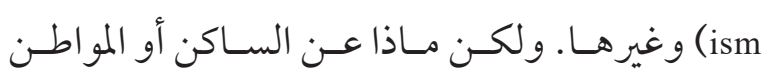

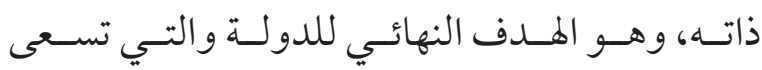
للسـيطرة عليـه وإخضاعـه ضمـن برنابجهـا السـياسي

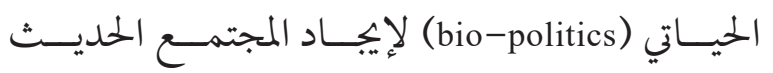

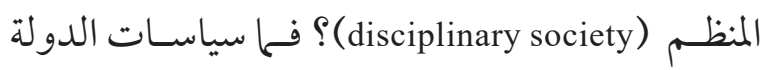

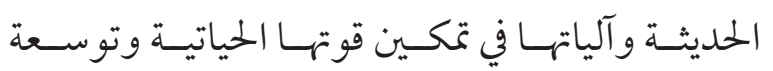

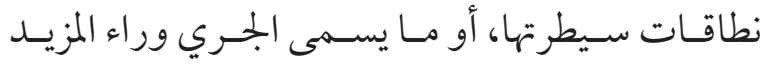
مـن القــوة (lust for power)، إلا لتحقيـق هـــا الهدف. لقــد حاولـت الدولـة الحديثـة تحقيـق ذلـك جزئيساً

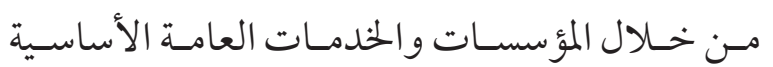

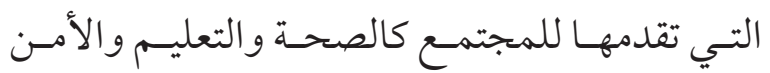

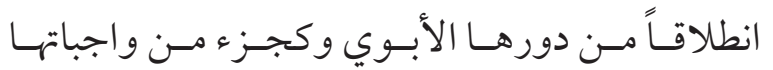
في دولــة الرفاهيـة. أي أن الدولـة الحديثة اسـتطاعت

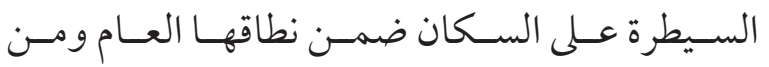

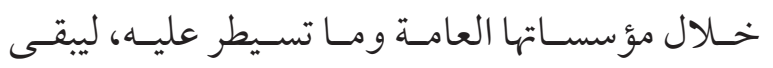

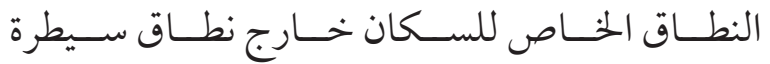

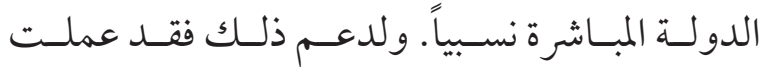

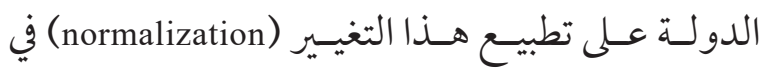

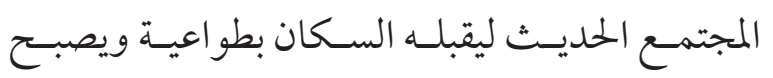

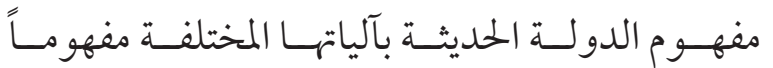

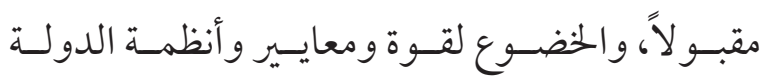

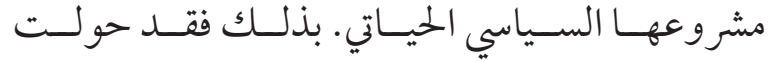

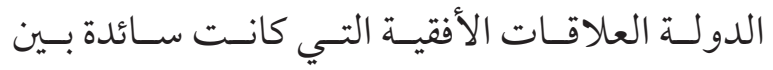

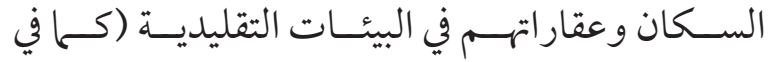
المـدن الإســامية) إلى علاقــات رأســية. فالســاكن

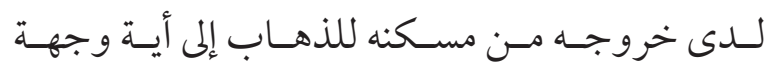

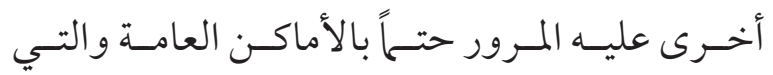

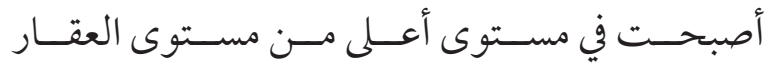
الخـاص مــن حيـث السـيطرة و القــوة. أي أن البيئسة

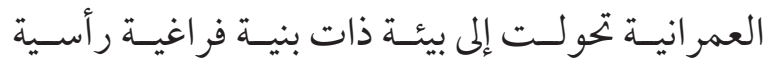

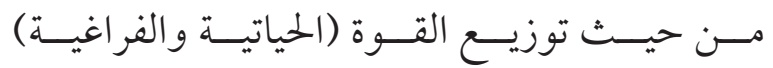

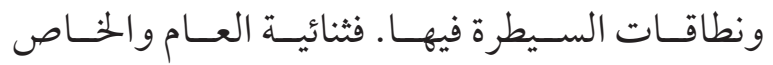

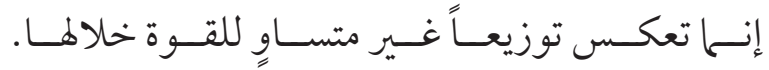

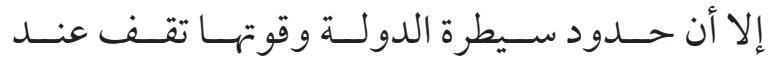

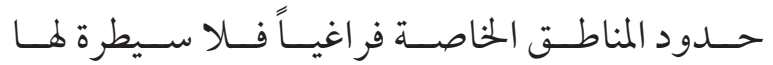
بداخلهـا. لـــا ولتتمكـن الدولـة مـن توسعة نطـاق

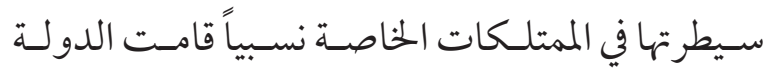
بامتـلاك البنيـة التحتيـة كخطــوط الكهربــاء والميـاه

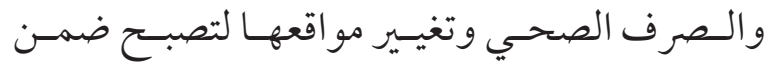

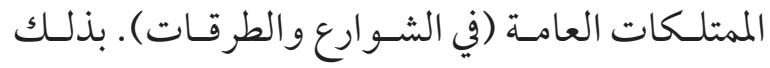
حولــت الدولـة خدمــات البنيـة التحتيـة التي توفرها

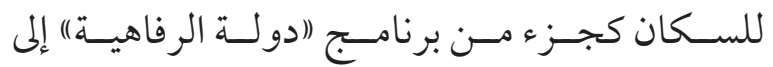

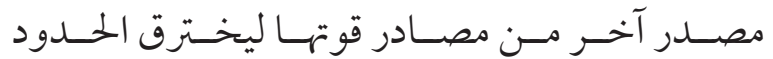
الفر اغيـة للمناطـق الخاصـة نســياً.

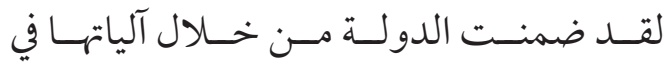
عمليـة التشـكيل المناطقي للقـوة و العمر ان؛ السـيطرة

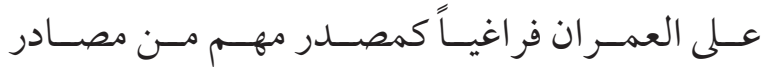

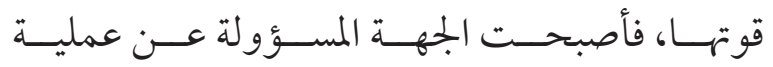

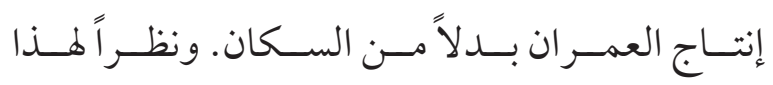


كريفـي (Krivy, 2018) وسادوســي (Sadowski)

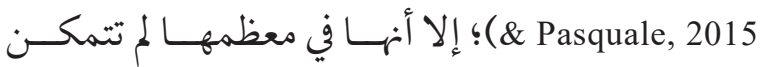
مــن تحليــل الجانــبـ السـياسي في المدينــة الذكيــة بشـكل عميـق بالتركيـز عـلى مفهـــوم القــوة وآليـات عملهــا، بــل بقيـت تــدور في نفــس الفلــك الــــي

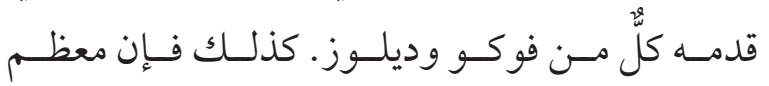
هـذه الدراســات لم تكــن معنيـة بالجانـب الحـضـري التخطيطـي للمدينــة حيـث قـام بهــا باحثــون مـنـ

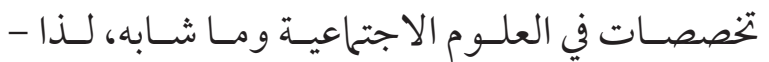

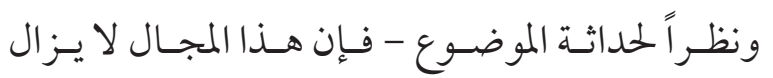

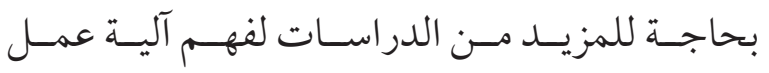

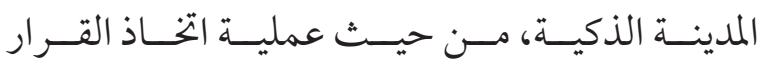

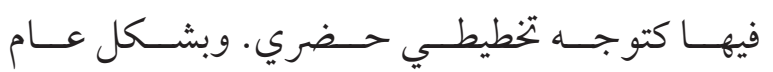

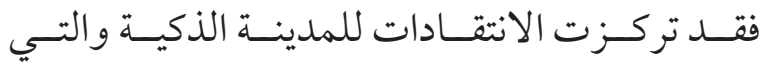

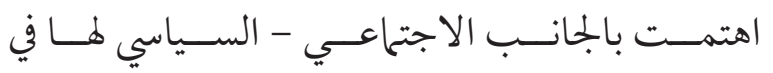
ثلاثـة عحـاور : الأول: والـــي ينظـر إلى المدينـة الذكيـة

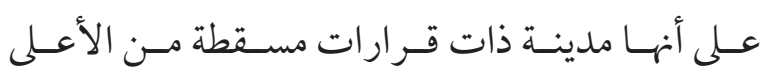

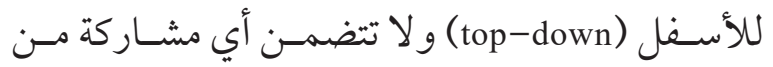

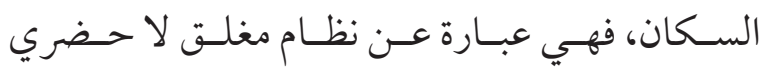
(anti-urban)

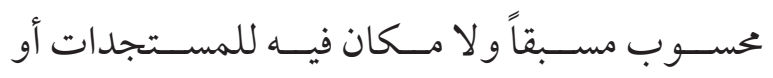

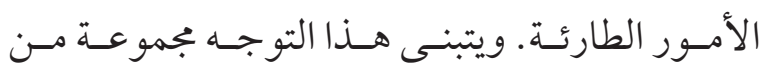
الباحثـين مثـل : ســينيت (Sennett, 2012) وساسـين (Sassen, 2012)

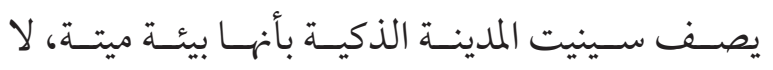
خيـار ات فيهـا للسـكان، بـل كل شيء مسـقط عليهــم

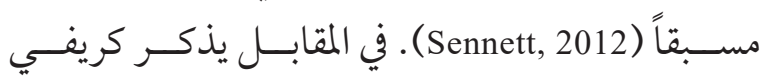
(Krivy, 2018)
أمـر أ ضروريـاً يعتـبر الخــروج عنــه خخالفـة. وهكـذا

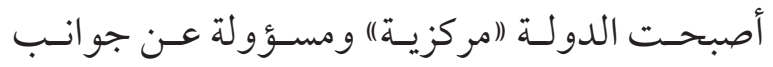

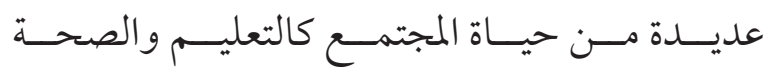

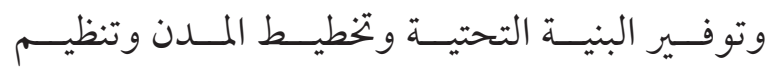
العمـران. فتـم بذلـك تسـييس معظـم جو انـب حيـاة

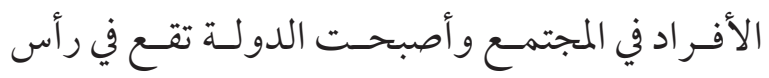

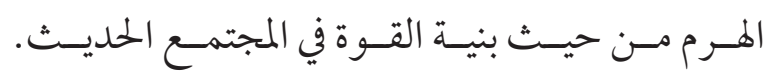

\section{r. تحو لات القوة في المدينة الذكية}

يذكـر ديلـوز في مقالتـهـ لعـام ب999 أن مفهـوم

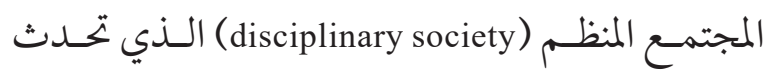

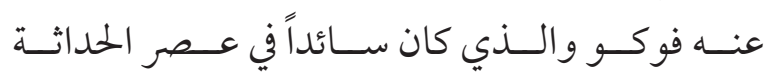

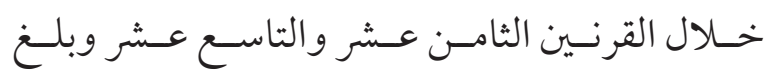

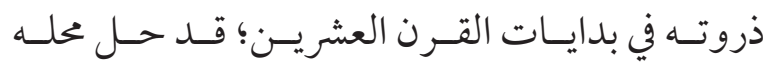
اليـوم ججتمـع السـيطرة (society of control) و الــذي

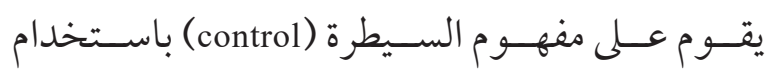

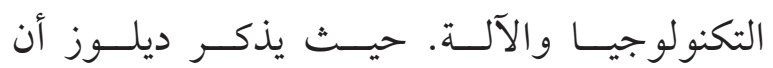
السـيطرة عـلى المجتمعــات اليـوم تقـوم عسلى السـيطرة

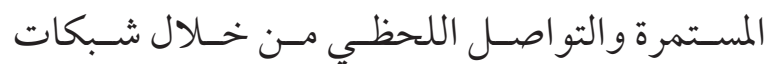

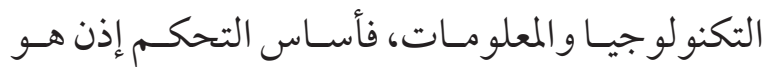
وجــود شـبكات تربــط عنـاصر المجتمــع(subjects)

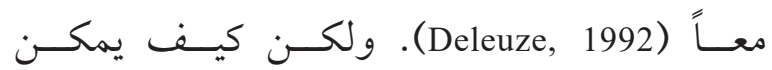
قــر اءة هــذا التحـــول في مفهـــوم القــوة مــن المفهـــوم الفوكـــودي الحديــث إلى المفهــــوم الديلــوزي؟ رغـــم أن هنــاك العديــــ مــن الدراســات

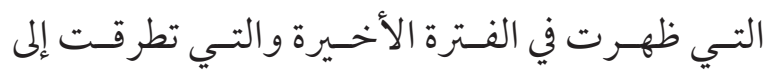
مغهزهـوم القــوة (bio-power) لـــى فوكــو وكذلـك مغهـوم ججتمــع السـيطرة لــدى ديلـوز مثل: دراسـات 


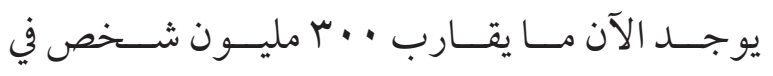
الهنـــ يعيشـون بـدون خدمــات كهربــاء وبنيـة تحتيـة،

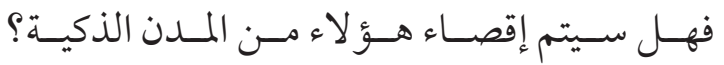
ولفهـــم حيثيـات المدينــة الذكيـة سـيحاول

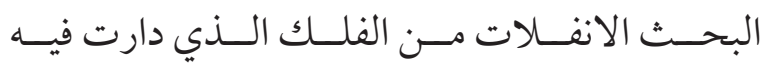

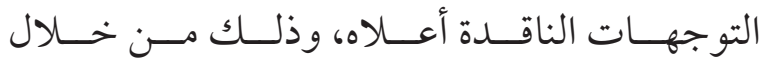

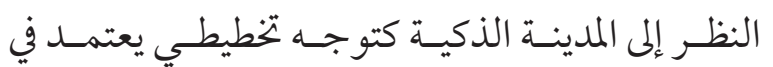

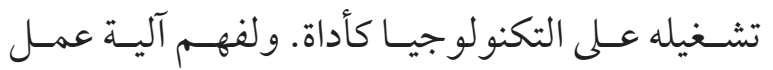

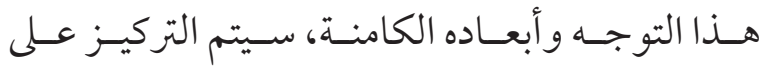

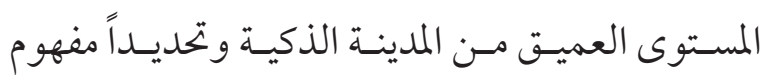

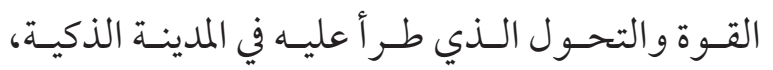

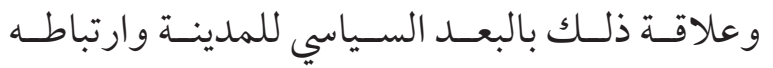

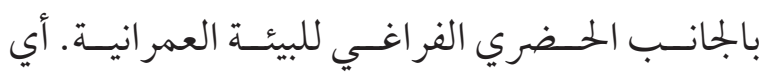

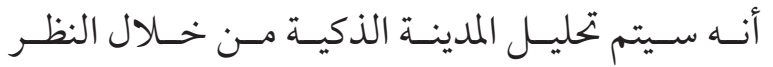

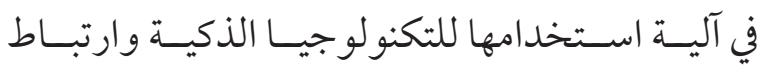

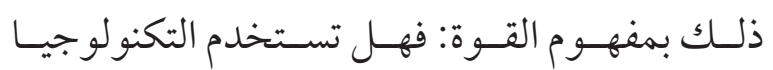
في المدينـة الذكيـة كأداة لتسـهيل حيــاة السـكان كــا

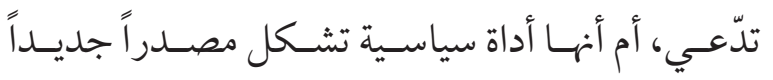

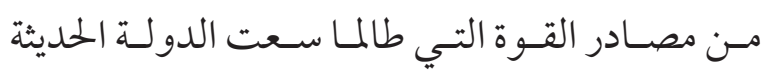

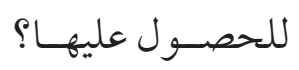
بحســبـ طــرح هــذا البحـــث فــإن المدينــة

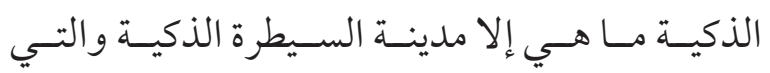

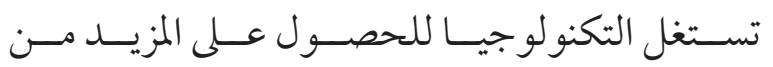

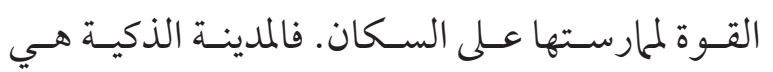

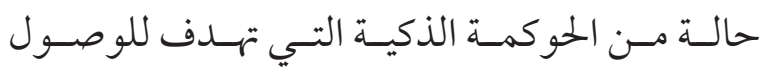

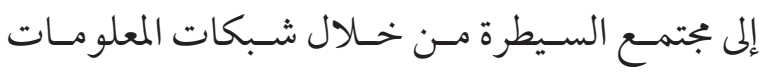
والاتصـال. كيـف؟ الف
الذكيـة تتضمــن منطقـاً في ممارسـة القـوة يختلـف عـما

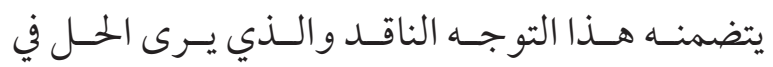

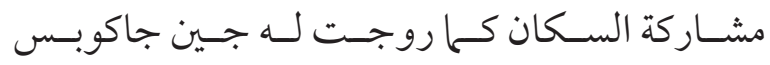

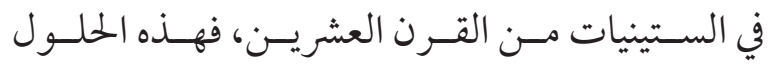

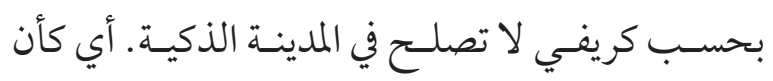

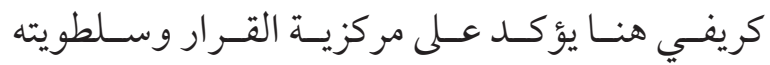

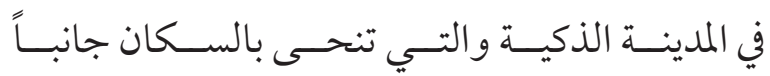

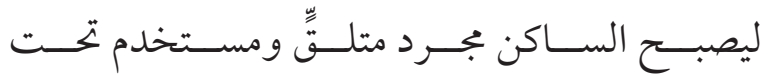

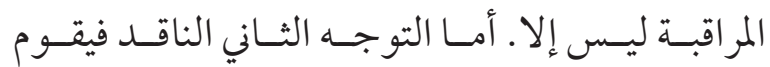

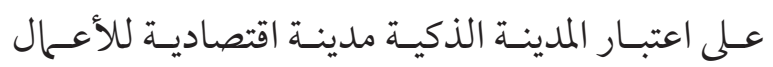

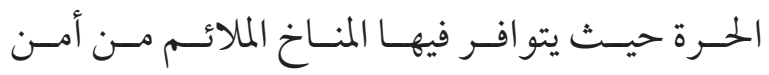

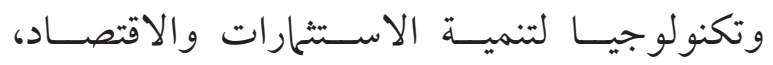

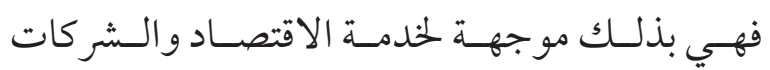
الكــبرى. أي أنهــا مدينــة رأســـالية للر أســـاليين،

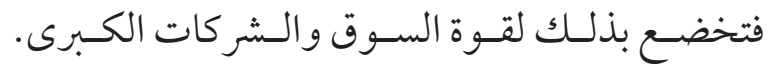

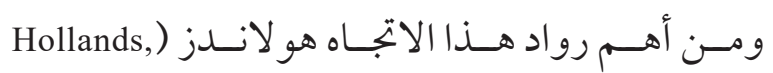
2008) وكيتشـين (Kitchin, 2014). ويركـز التوجـهـ

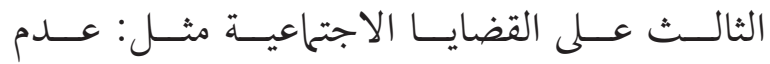

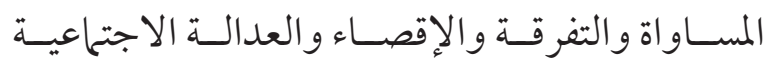

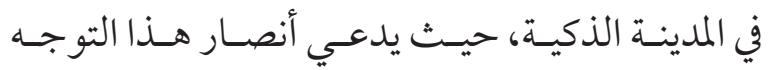

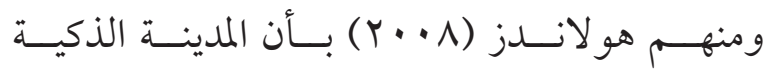

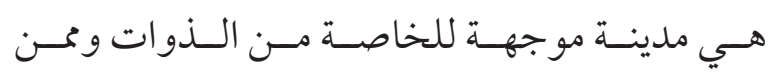

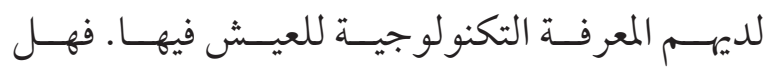

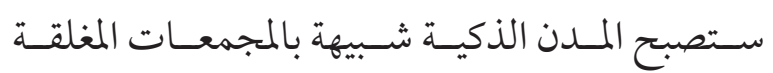
(gated communities)

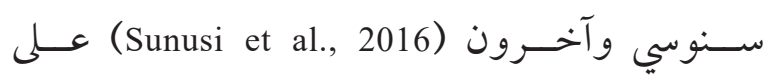

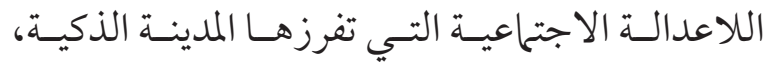

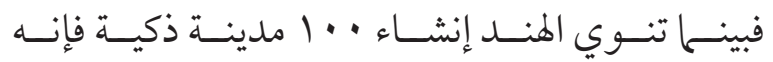


ولـوج السـاكن إلى نطاقـه الفراغـي الخـاص كمنزلـهـ

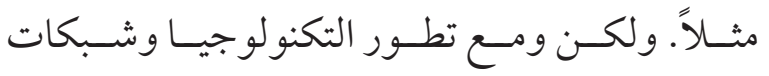

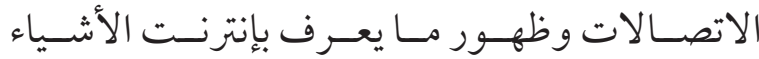
واسـتخدامات ذلـك في (Internet of Things- IoT)

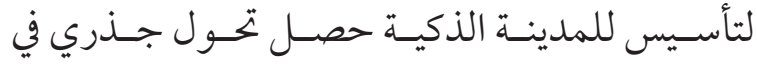

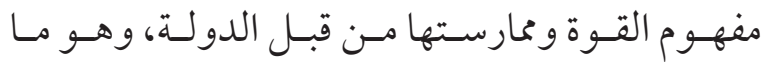

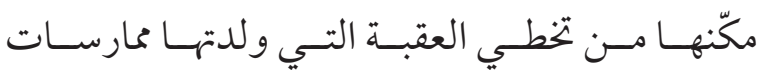

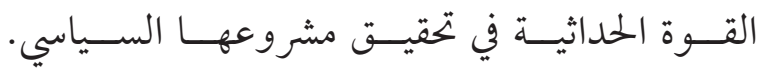
كيـف؟

تشـترك القـوة بمفهومهــا الحداثي ومفهومهـا

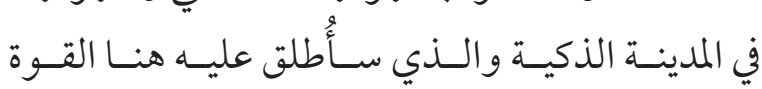

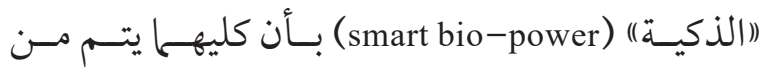
خــلال ممارســات الدولــة للقــوة بهــــف السـيطرة

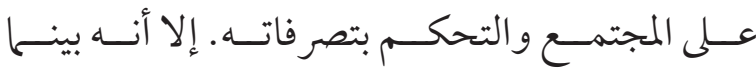

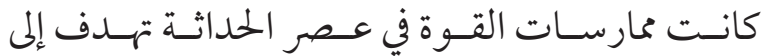

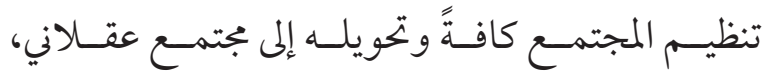

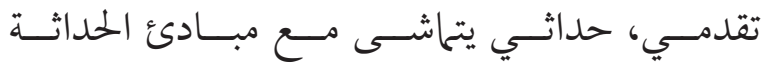

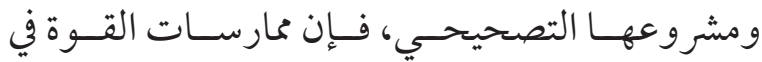

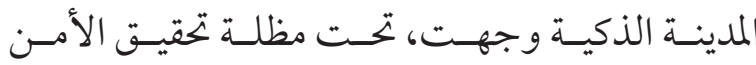

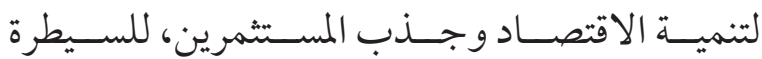

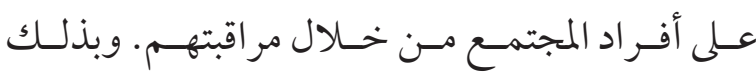

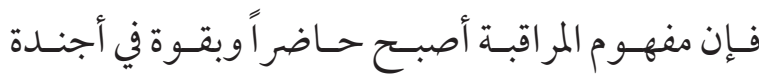

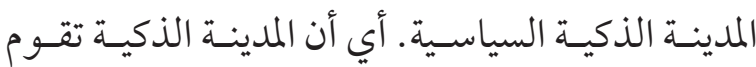

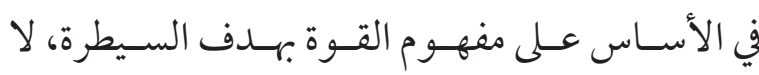

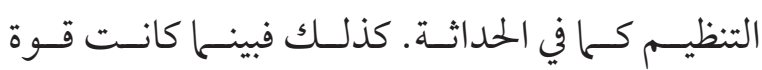

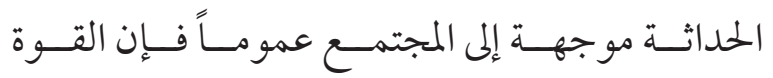

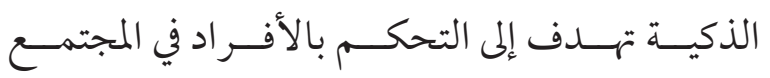

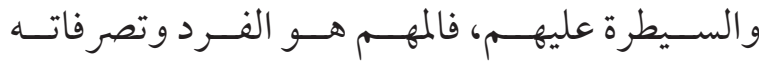

لقـــ اعتمـــت القــوة الحديثـة كـا ذكرنـا أعلاه

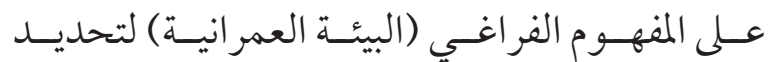

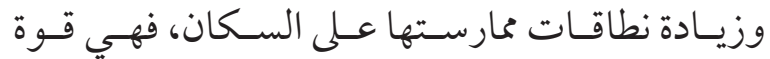

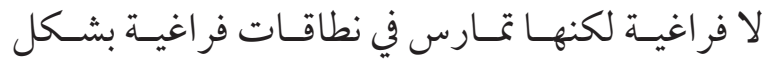

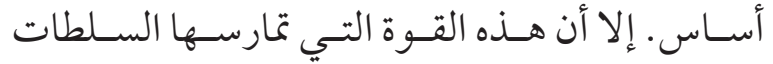

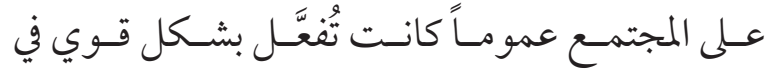

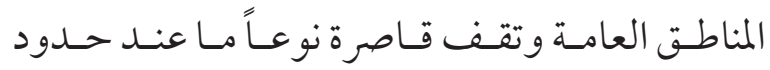

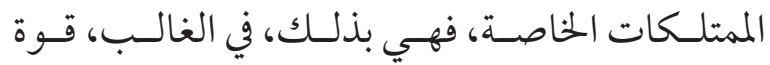

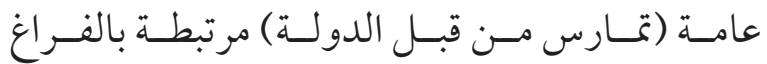

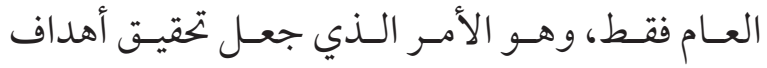

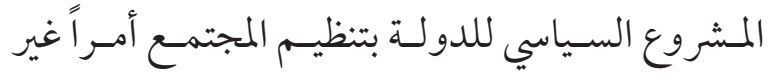

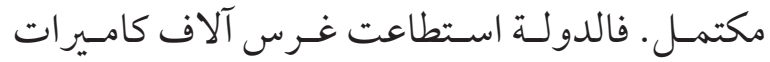

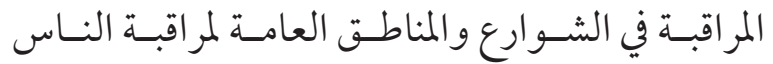

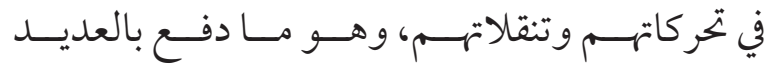

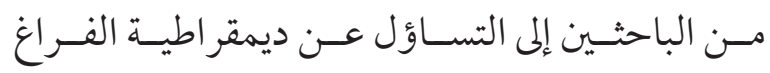

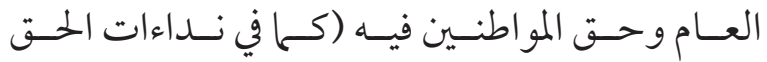

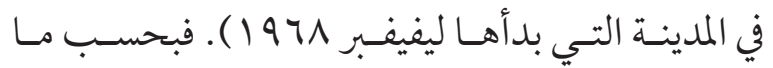

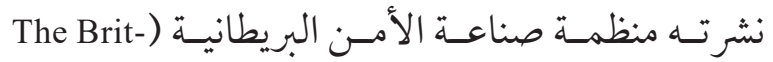
(ish Security Industry Association

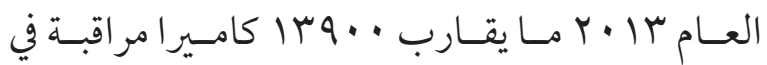

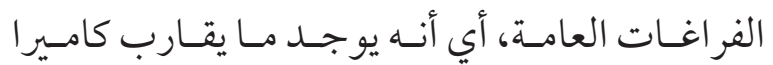

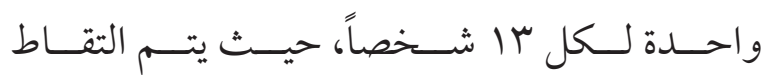

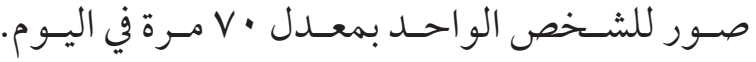

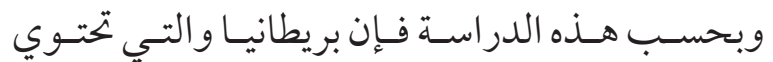

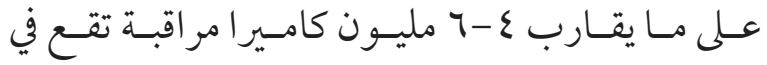

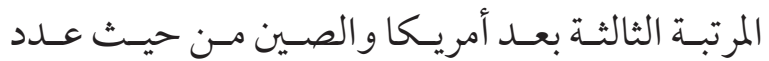

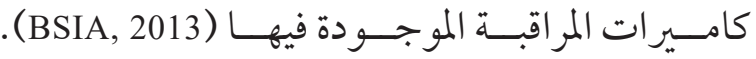

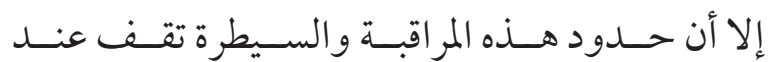


كذلـك. فهي متشـعبة وتطـال كافـة جزئيـات الحيـاة

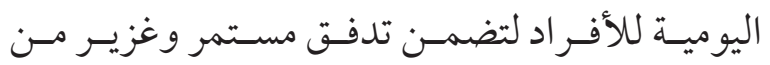

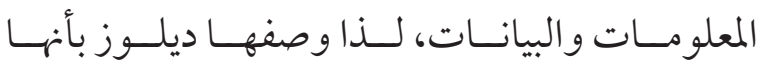

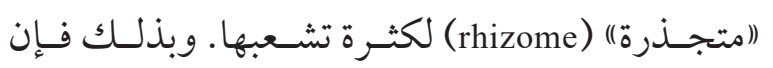
الحــدود القويــة الفاصلــة (boundaries) في ثنائيــة

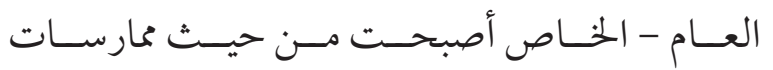

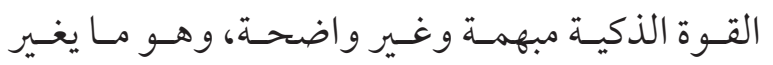

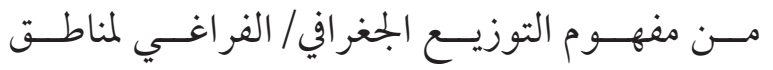

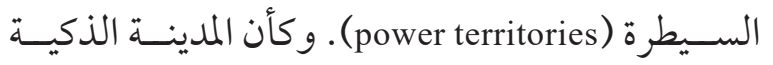
أصبحــت أشــبه بالســجن الذكـي (smart panopti-) (can هـذا المججـال تشـير هــار اوي (Haraway) إلى الانتقــال

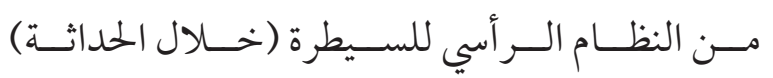

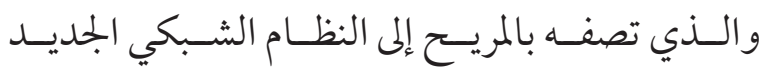
(في المدينـة الذكيـة) والـذي تصفـه بالمخيـف (scary)،

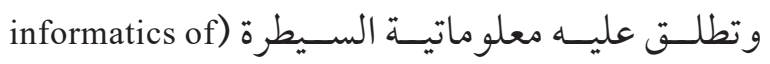
Sadowski \& Pasquale, مقتبـس مــن (domination 2015). كذلــك فتــــ اســطـاعت الدولــة الانتقـــال

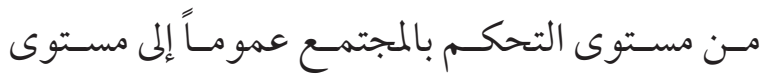

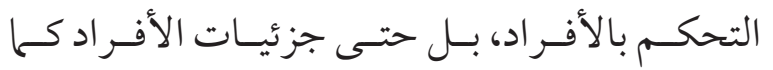

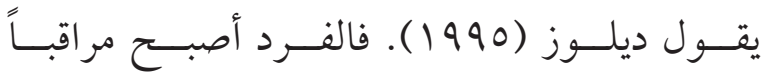

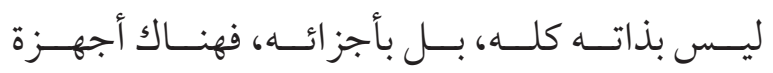

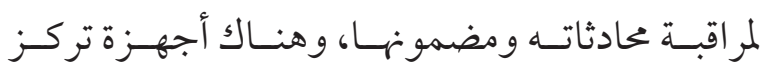

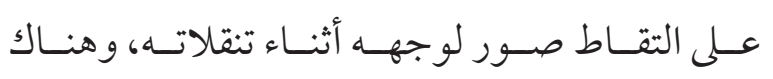

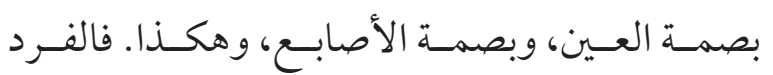
(individual) عـلى ذلـك مصطلــح "(جـز زء الفــرد) (dividual) . أي

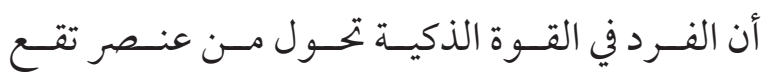

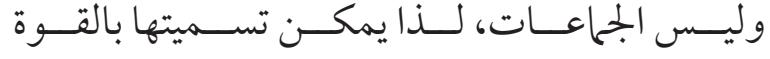

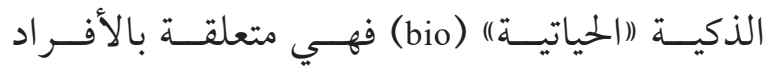

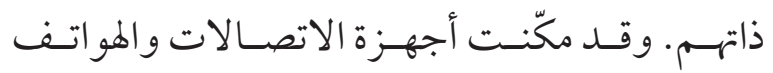

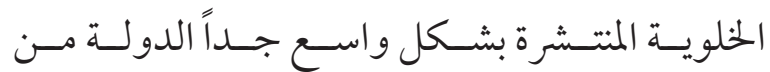
تحقيـق مشروعهـا السـياسي ذاك. فقـد تحـــــ الإنسـان

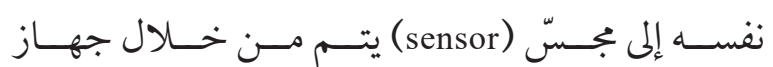

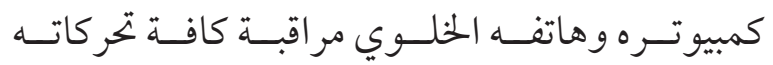

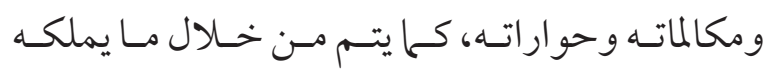

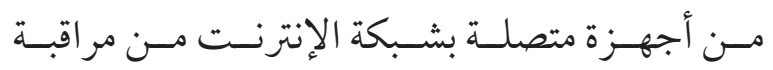
و معرفـة تفاصيـل دقيقـة عـن حياتـهـ اليوميـة. فالدولة تراقـب المو اطنـين في تنقلاتهــم بوســائط النقـل العـام مـن خـلال بطاقـات التأمـين كالفيـز اكارد وبطاقـات

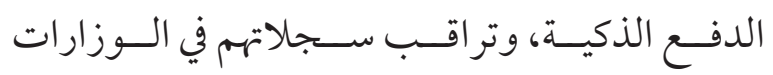
و الدوائــر الحكوميـة، وتر اقـب سـفرهم مــن خـالال

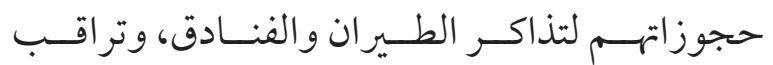
كميـات اسـتهالاكهم للكهربــاء والمـاء و الغــاز مـنـ

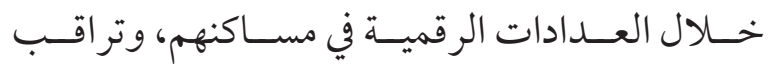

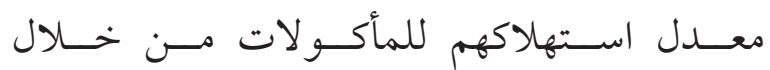

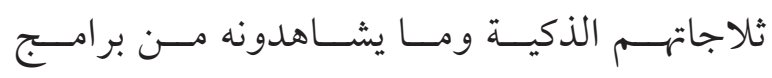

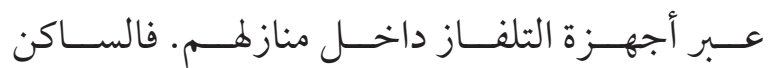

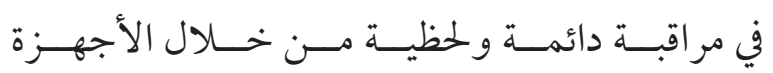

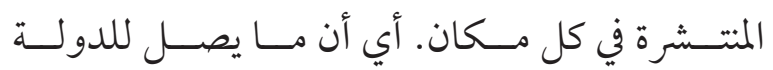

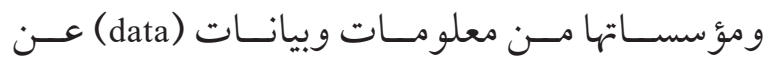

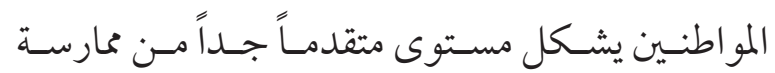
القــوة عــلى الســكان يفــوق مـــا اســـطاعت القـــوة

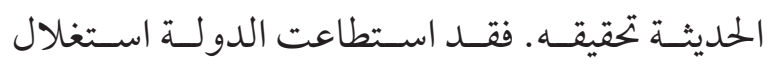

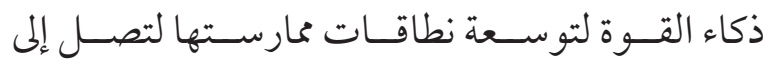
المناطـقت الفر اغيــة الخاصــة للأفــــاد، بــل الحياتيــة 
أنهـا تحولــت في محورهــا مــن العمـــران أو الجلغر افيــا

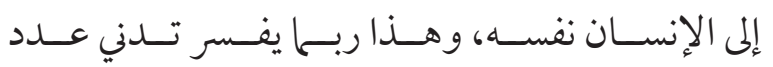

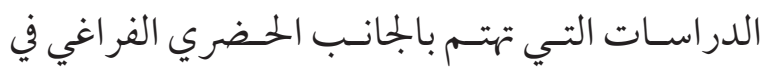

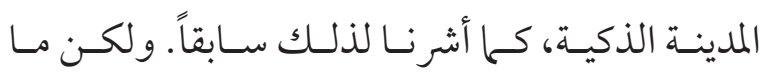

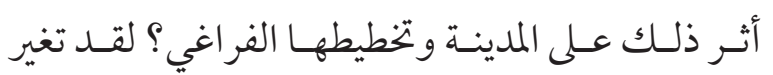

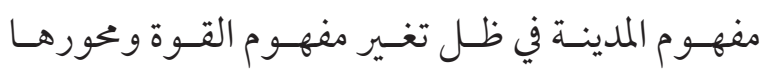

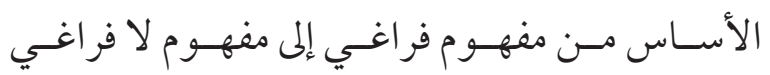

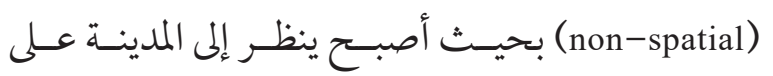
أنهـا جــرد ظـرف مـكاني أو وعـاء (spatial container) يهـوي الحــدث ويسـهل حركياتـه، فهـي وعـاء للقيـام بالأنشــطة الذكيـة ومـكان لملمارسـة القــوة والتحكـــم مــن خــلال أجهــزة المراقبــة و الشــبكات الرقميــة.

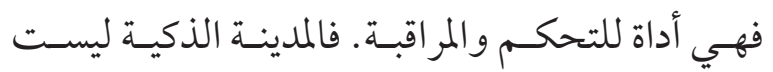

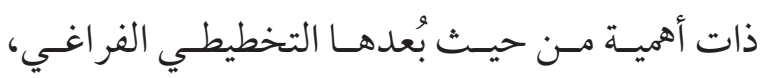

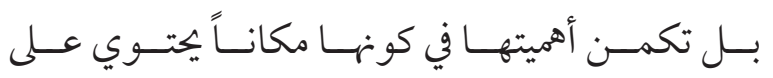

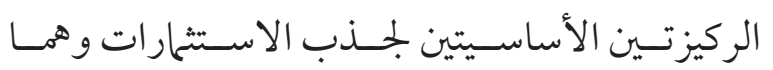

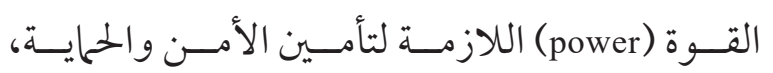

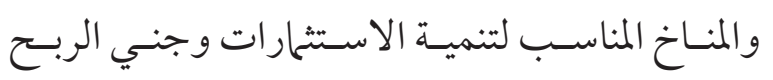
كو جـود شـبكات التكنولو جيـا و الاتصالات (profit)

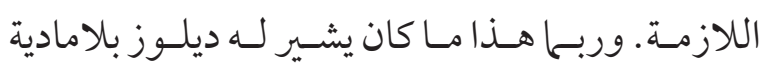

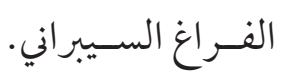

كذلـك فـإن القــوة الذكيـة تتســـم بأنهـا قـوة

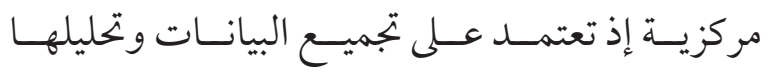
(Big data)

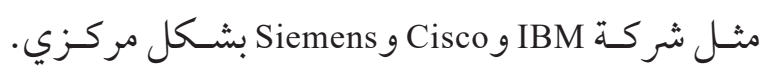

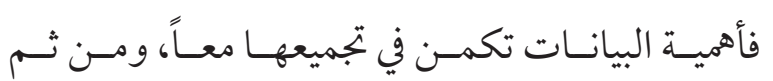
تقـوم مؤسسـات تابعة للسـلطات الحكوميـة بتحليلها

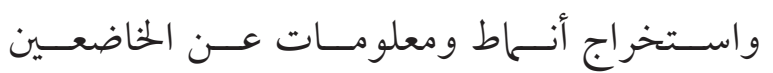

عليـه القـوة ويخضــغ لهـا كـا في الحداثـة إلى جـزءء مـن نظـام القـوة نفسـه، فهـو يتيـح للقـوة ممارسـتها عليه.

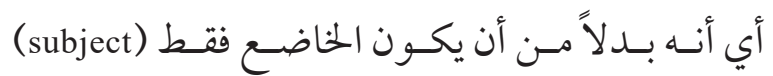

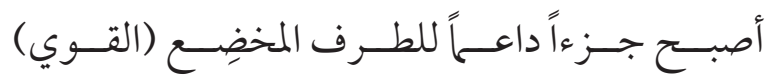

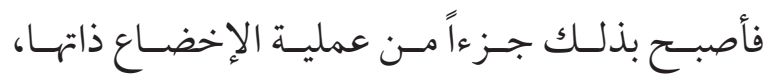

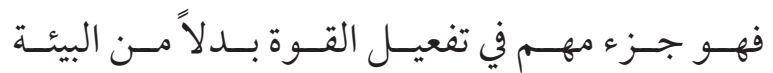

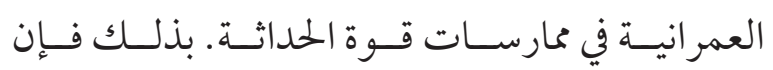
العلاقـة بــين الإنســان و المدينــة والتكنولو جيــا، كـــا

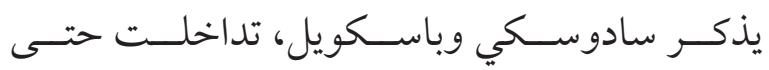

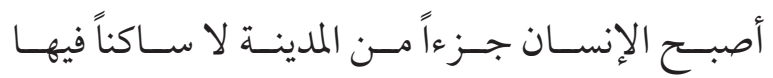
(Sadowski \& Pasquale, 2015)

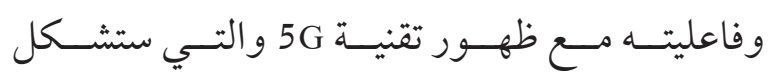
العصـب الأسـاس للمدينـة الذكيـة بـا تحتـوي عليـهـ مسن عـدد لا محسدود مسن نقـاط المجسّـات (sensors) المترابطـة معــاًعـــر الزمــان والمـكان. وبذلـك فــإن

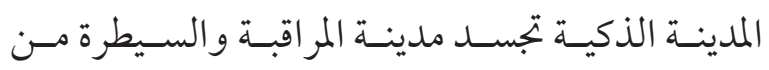

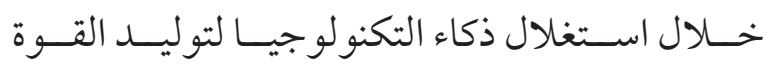

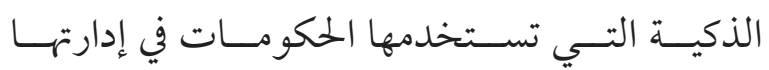

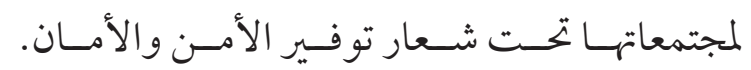

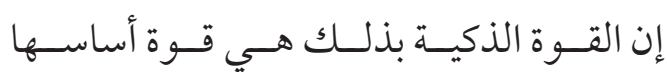

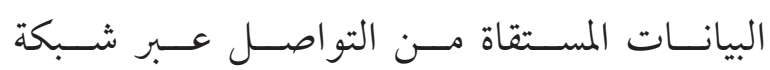
العلاقـات بــين النــاس والأشــياء مــن خــلاهل

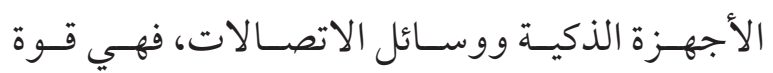

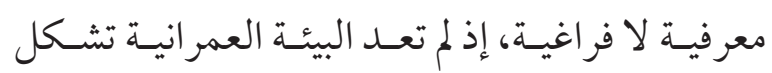

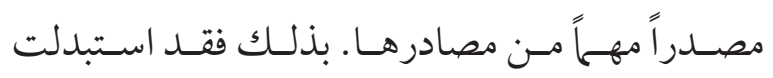

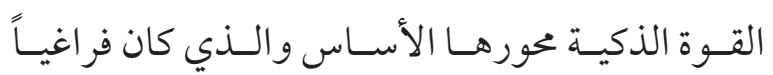
(البيئـة العمرانيـة) في الحماثـة بمحسـور لا فراغـي وهو

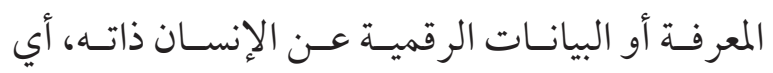




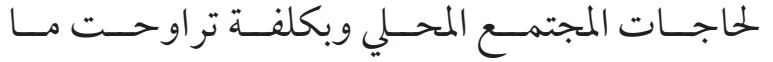

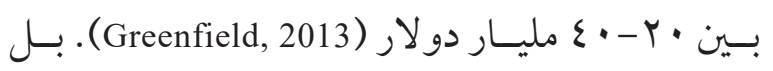

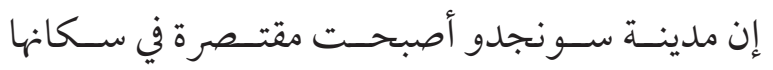

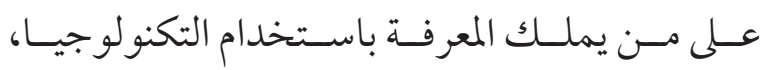

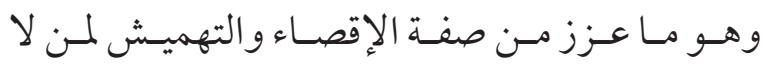

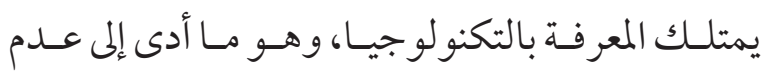

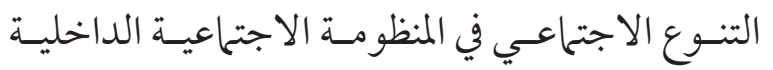

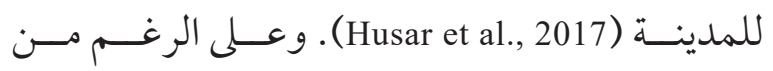

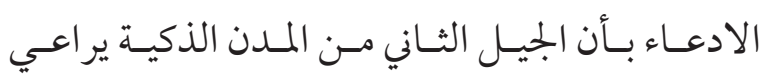

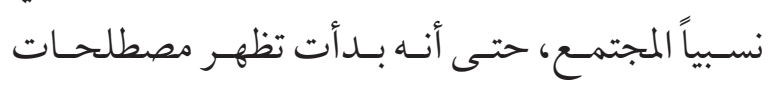

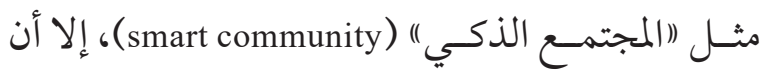

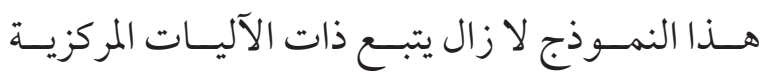

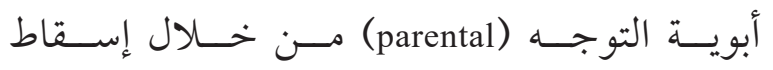

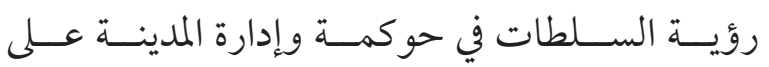

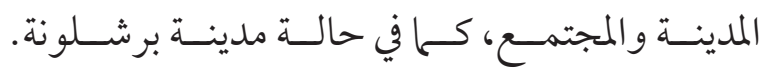

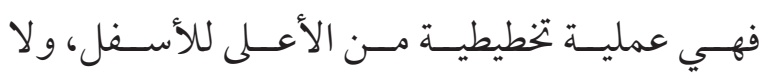

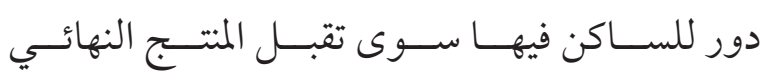

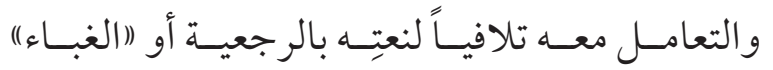
التكنولوجـي. فالـذكاء أصبـح صفــة ترويجيـة لتسـيير

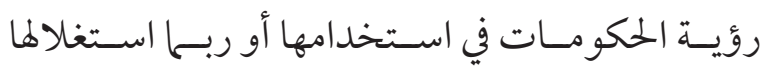
للقــوة لتحقيـق رؤيتهـا في السـيطرة. إن المدينـة الذكيـة كتوجـهـ تخطيطي إنـا تعـود

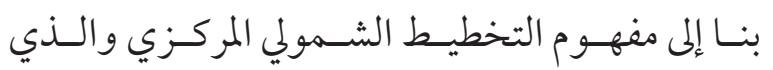
أنتــج في عصـر الحداثـة مدنـاً جديـدة مخططـة، كمدينة

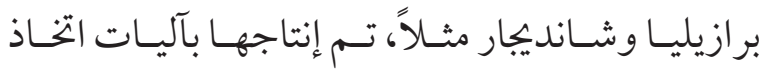

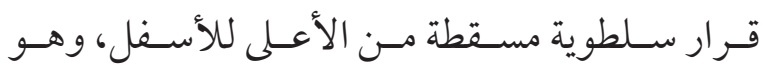

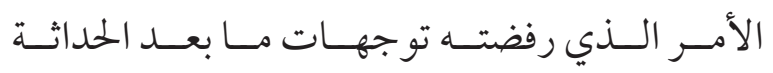

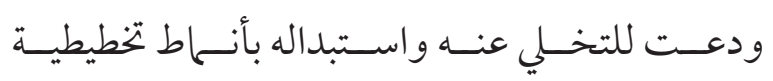

تفيـد في عمليـة التحكـــم و الســيطرة عليهـم، كــا في

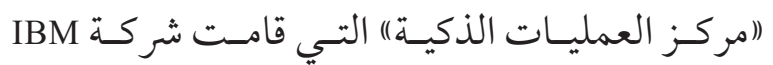

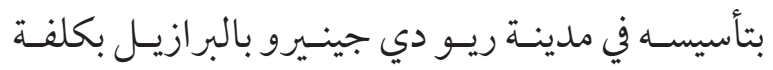

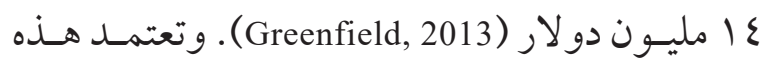

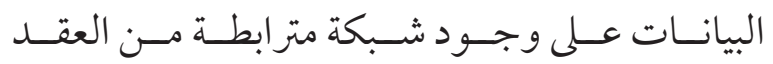

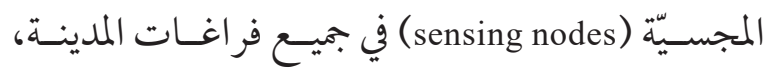

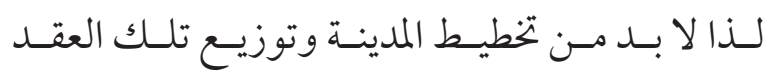
و الشـبكات بشـكل مركـزي مسـبق لتشـكل بدورهـا

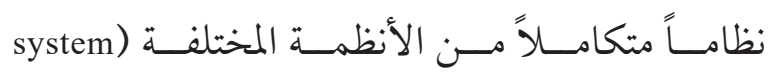

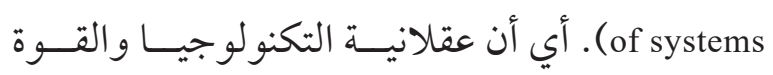
rationality of smart power - technological ratio-) فnalism هـي التـي تتحكــم بتخطيـط المدينـة لضــان

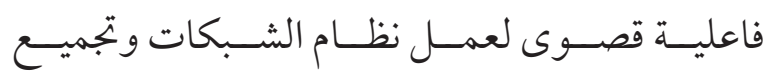

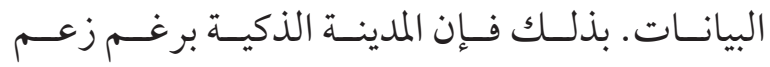

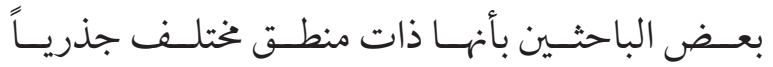

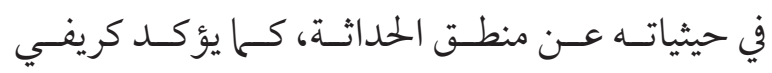

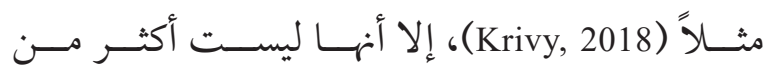

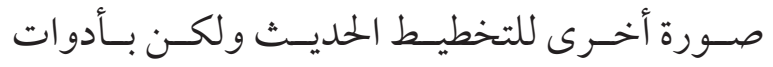

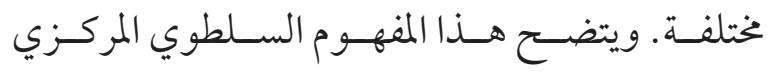

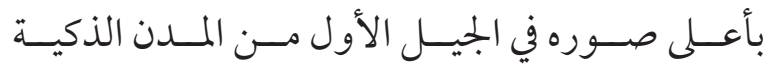

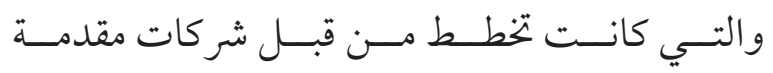

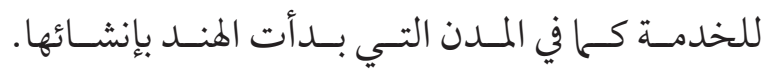

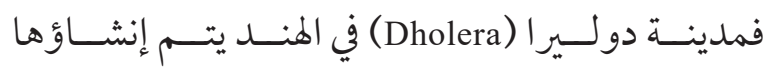

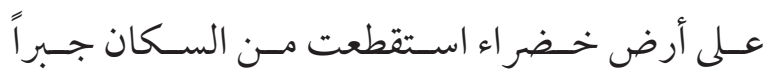

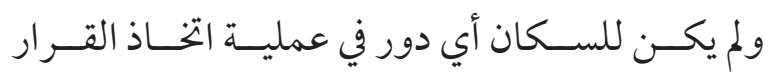

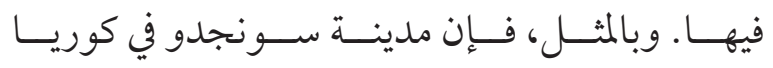

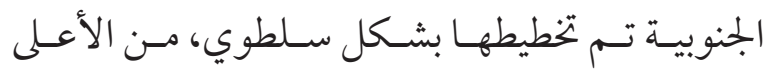

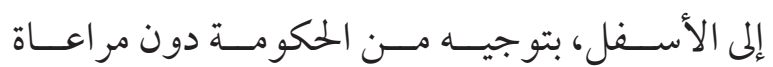


السـعادة والحيـاة الأفضـل لسـكانها كـما حلمـت بهـا

$$
\text { البشريـة؟ }
$$

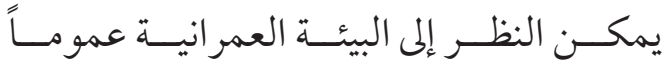

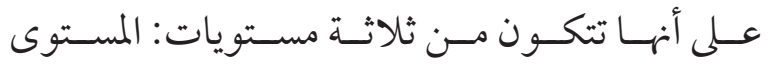

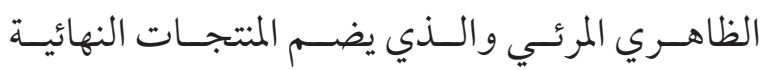

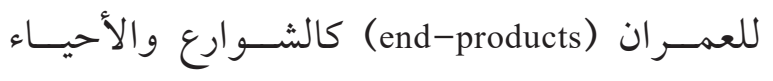

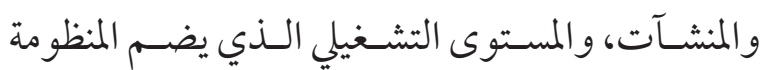

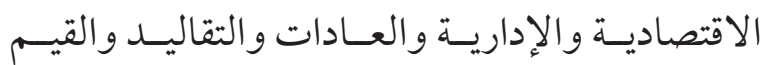

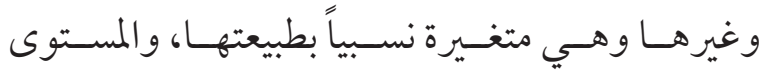

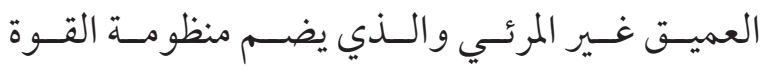

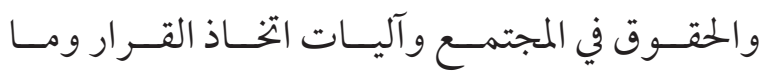

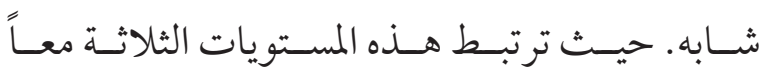

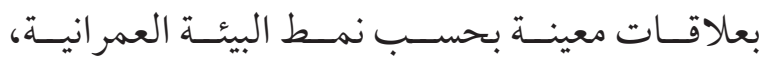

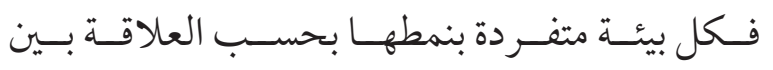
مسـتوياتها ســواء البيئــات التقليديــة (كالإســلامية

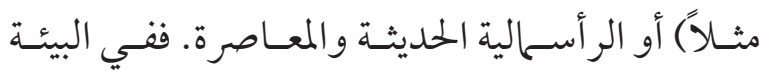

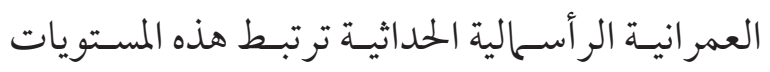

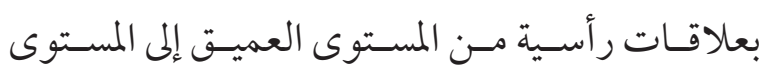

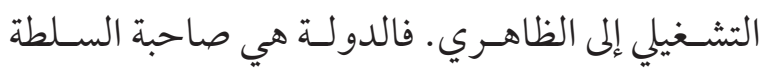

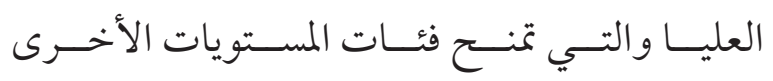

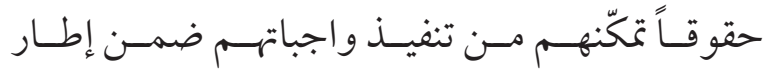

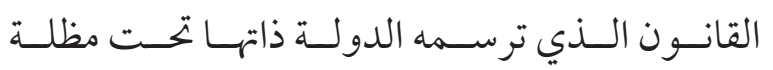

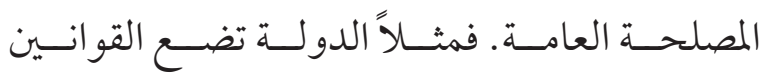

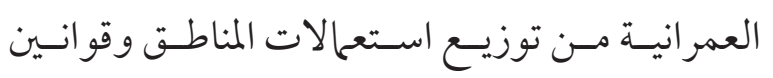

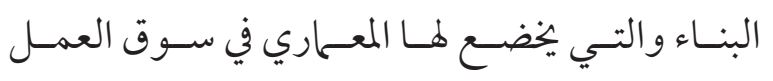
في المسـتوى التشـغيلي ليتلقاهـا المسـتخدم (الســاكن)

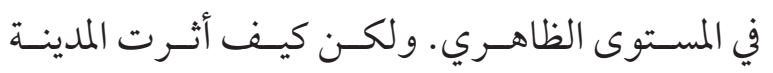

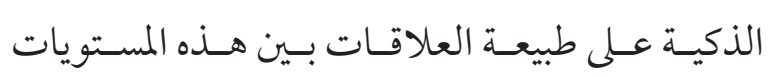

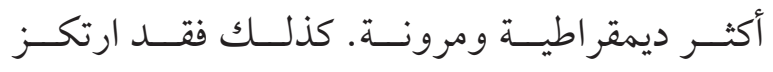

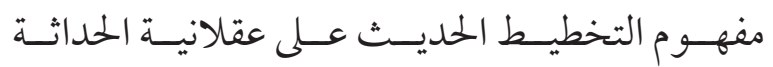

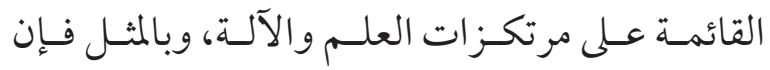
عقلانيـة المدينــة الذكيـة تقــوم عـلى عقلانيــة القــوة

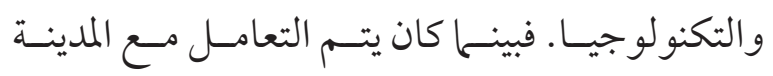

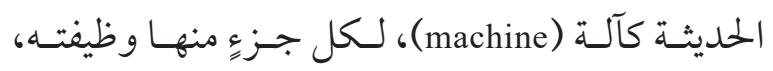

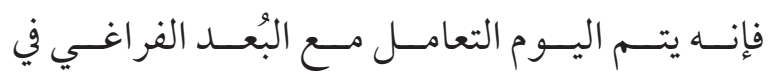

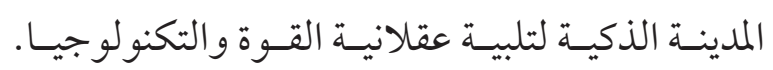

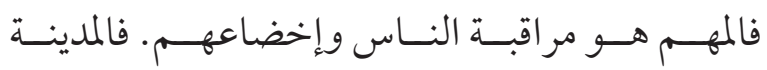

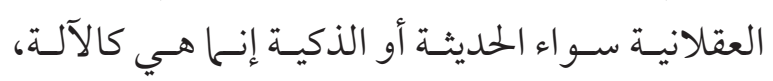

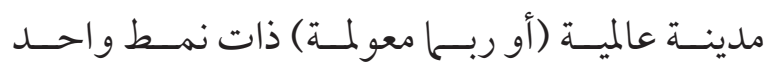

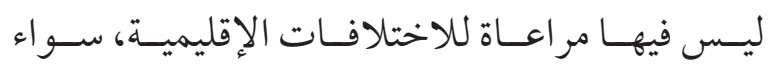
كانـت في ريـو دي جينـيرو أو سـنغافورة أو برشـلونة.

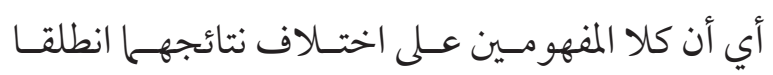

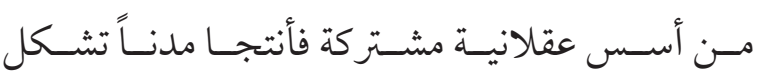

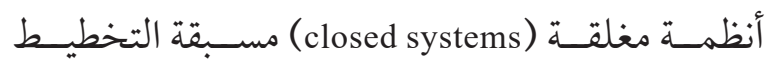

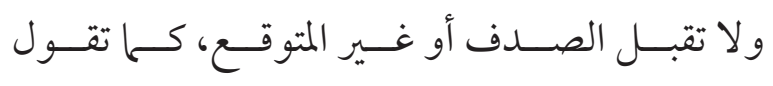
ساسـين (Sassesn, 2012).

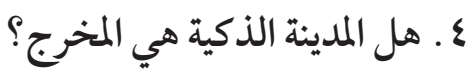

طالــا أن هنـاك خطو طـاً متقاطعـة بـين منطـق

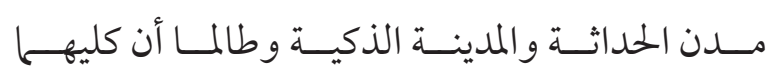

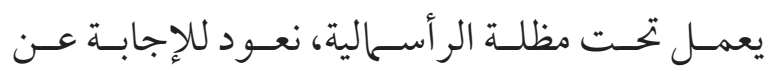

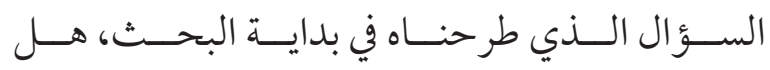

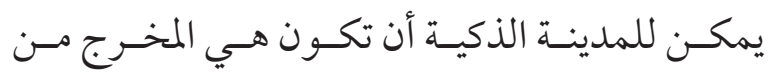

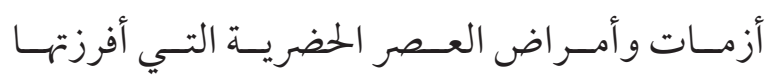

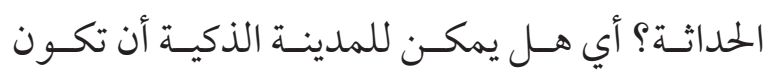

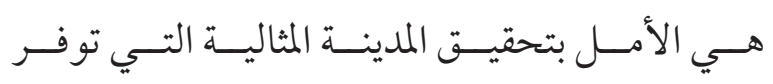


آليـات عمـل المدينـة الحلديثـة والذكيـة هـي ذاتهـا،

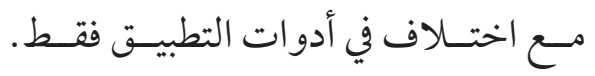

لـــذا فــإن الأمـــــاض والأزمــات الحضريــة

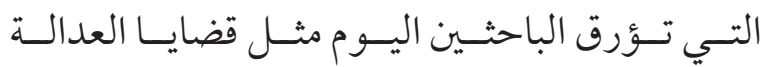

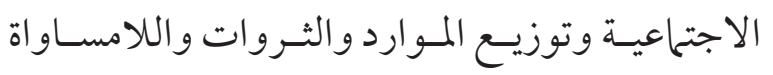

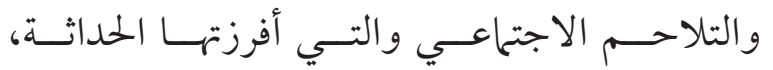

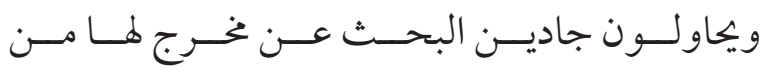

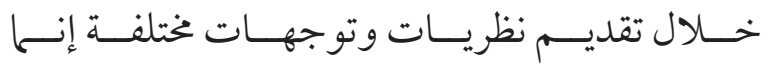

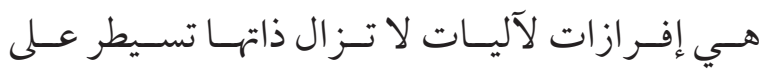

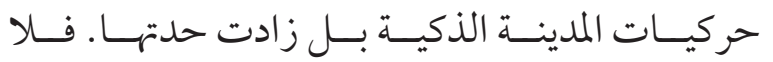

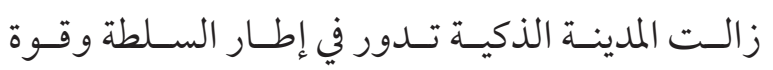

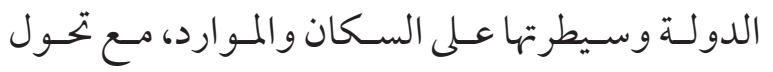

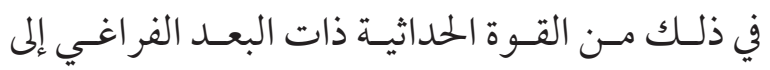

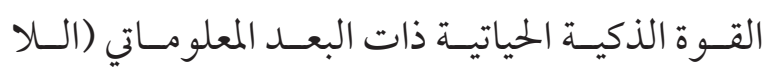

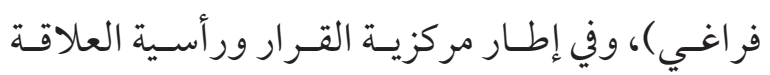

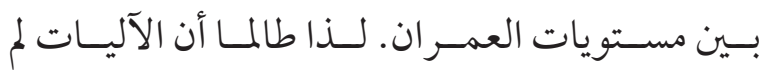

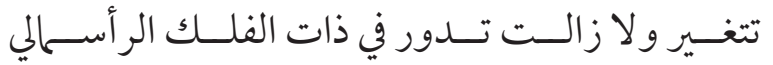

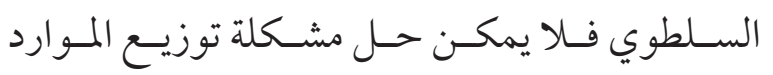

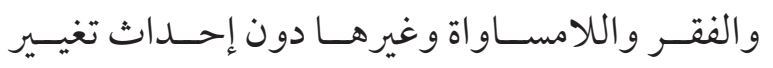

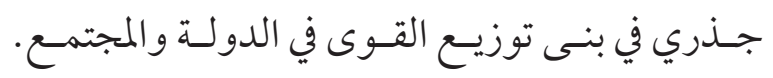
إن الحريسة التـي نـادت بهـا الحداثـة والتنويسر

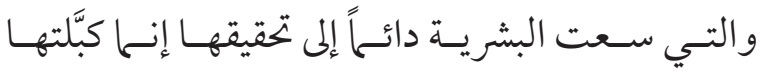

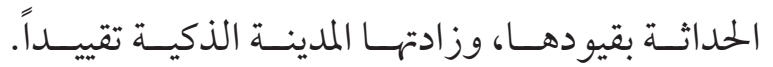

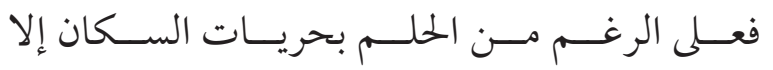

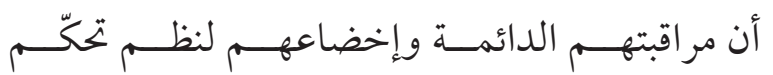

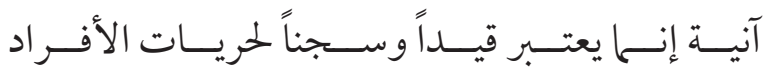

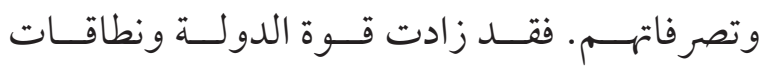

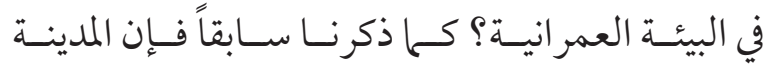

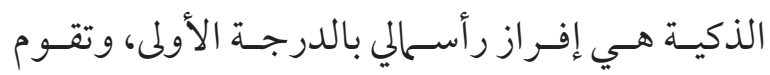

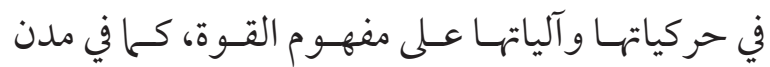

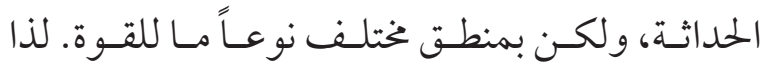

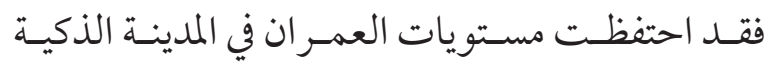

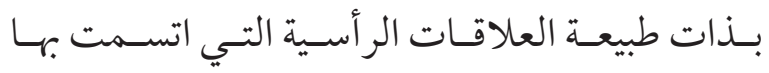

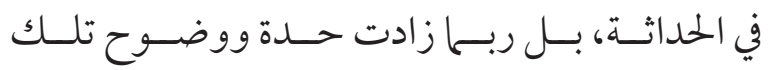
العلاقـات. فنتيجـة لازديـاد قـوة الدولـــة ومركزيتهــا

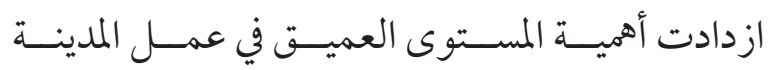

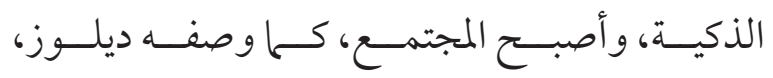

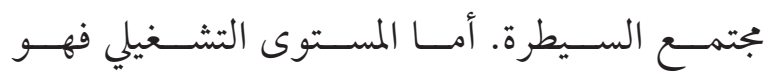

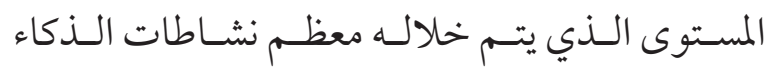

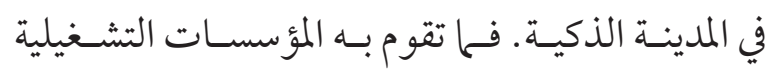

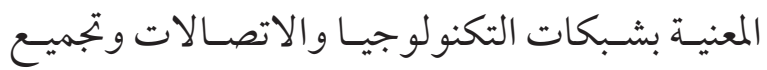
البيانــات الرقميـة كـشركات IBM و و و و mens

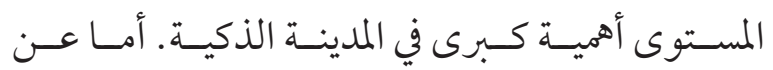

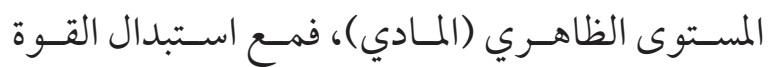

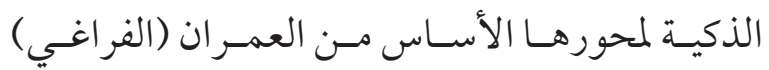

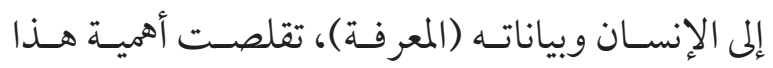

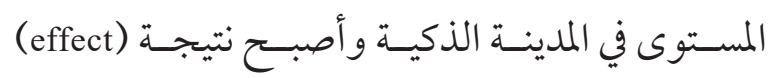

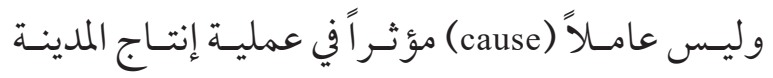
الذكيـة وتشـغيلها. ولكـن حيـث إنـ المسـتوى العميق

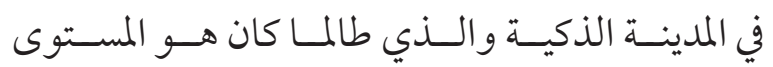

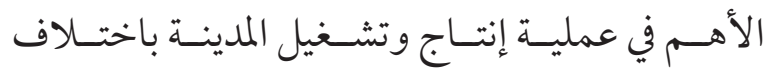

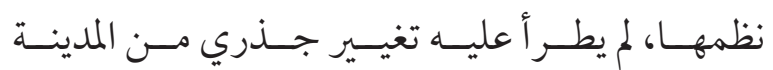
الحلديثـة إلى المدينـة الذكيـة، بـل ربــا ازدادت فاعليتـهـ

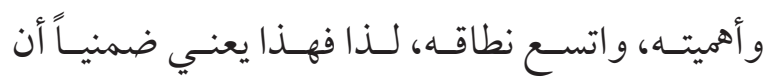


تجارب السـكان أنفسـهم، لا في إقصائهــم وإخضاعهم

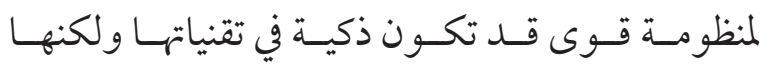

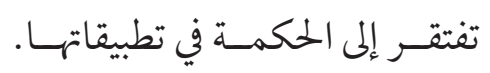

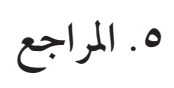

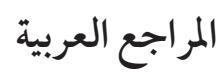

الجــار الله، أحـــــ الغامـدي، ســارة. (امفهــوم المدينــة في ضـــوء تطــور تكنولوجيــا المعلومـــات

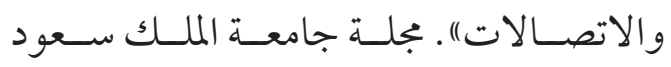

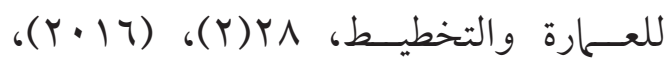

$$
\text { ص. }
$$

اللحــام، عبـير. (المشــهد الحــضري والمثاليـات

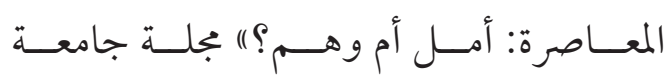

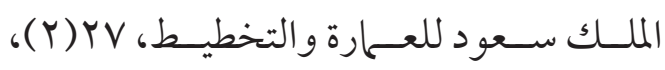
(r.10)

\section{Arabic References}

Al-Jarallah, A. \& Al-Ghamdi, S., "The Concept of Contemporary City in Light of ICT Development, The Journal of King Saud University for Architecture and Planning, 28(2), (2016), pp.155-179.

Allahham, A., "The Urban Scene and Contemporary Utopias: Hope or Fallacy?” The Journal of King Saud University for Architecture and Planning, 27(2), (2015), pp.313-335.

\section{English References}

Allahham, A., "Public Space as a Manifestation of Power Territorialization”. In Christa Reicher, Fabio Bayro Kaiser, Maram Tawil, Janset
ممارسـتها ومركزيتهـا عـلما كانـت عليـهـ في الحداثـة. كذلـك فــإن الفــرد في المدينــة الذكيـة بجــبر ودون

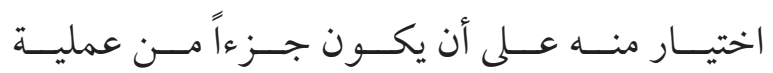

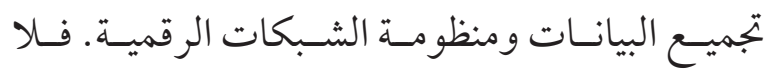

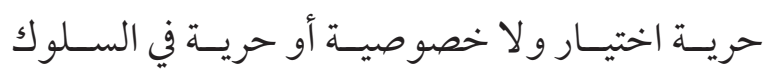

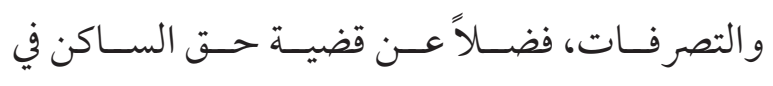
خصو صيـة بياناتـه واسـتخداماتها. إن المدينـة الذكيـة

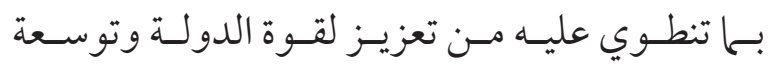

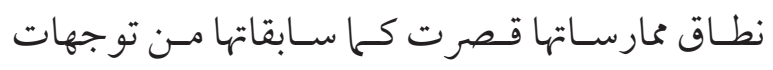

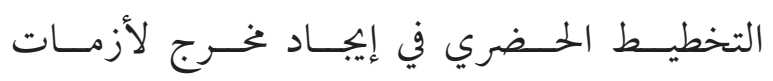

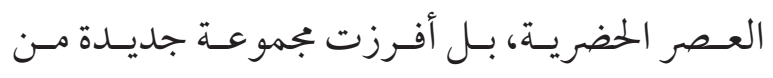

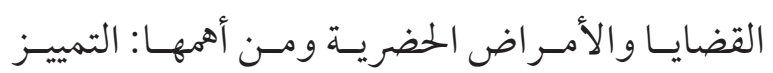

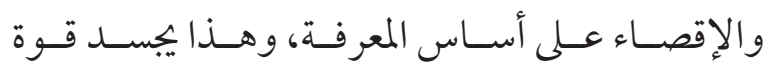

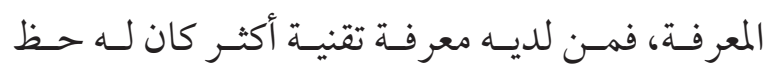

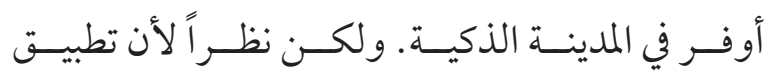

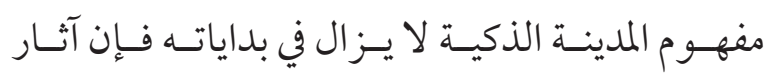

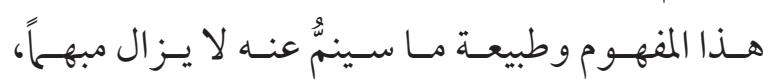

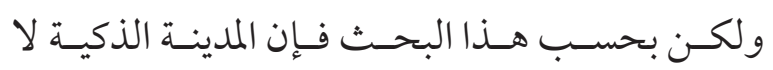

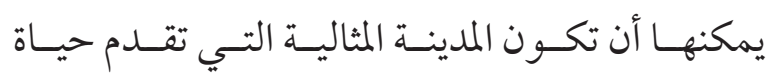

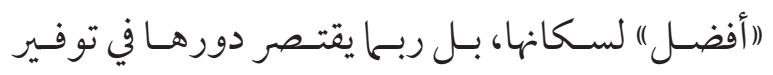

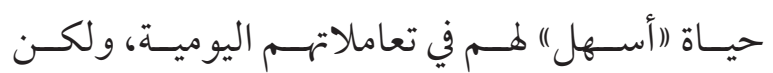

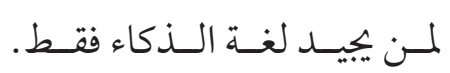

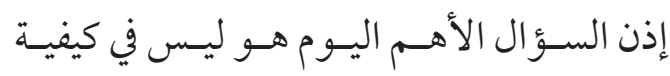

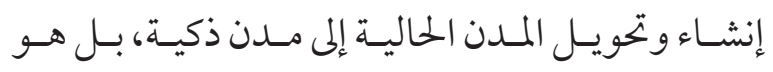
كيـف يمكــن اسـتخدام التكنولو جيـا كأداة لتحســين حيــاة الســكان وخدمتهـــم، لا الســيطرة عليهـــم

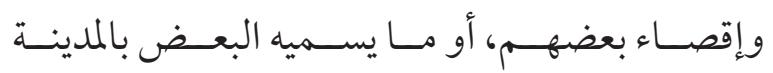

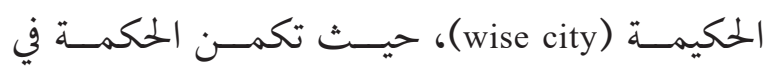


mentisfree/2012/dec/04/smart-city-riosongdo-masdar

Sunusi, A., Abba, S. and Iesha, R., "Smart Cities in India: a Theoretical Approach", International Journal of Science, Technology and Management, 5(12), (2016).

Vanola, A., Smartmentality: "The Smart City as Disciplinary Strategy", Urban Studies, 15(5), (2014), pp. 883-898.
Shawash, Karin Bäumer, Jan Polívka (eds.) Reclaiming Public Space through Intercultural Dialogue. Germany, Stadt- und Raumplanung (2019).

BSIA, "The Picture is not Clear". A report published by the British Security Industry Association, July 2013, UK.

Deleuze, G., "Postscript on Societies of Control”, October, 59, (1992), pp.3-7.

Deleuze, G., Negotiations, 1972-1990. New York: Columbia University Press, (1995).

Greenfield, A., Against the Smart City. New York: Do Projects, (2013).

Hollands, R., "Will the Real Smart City Please Stand up?" City, 12(3), (2008), pp.303-320.

Husar, M.; Ondrejicka, V., and Varis, S., "Smart Cities and the Idea of Smartness in Urban Development: A Critical Review", IOP Conference Series: materials Science and Engineering 245, 082008, (2017).

Kitchin, R., "The Real-Time City? Big Data and Smart Urbanism", GeoJournal, 79, (2014), pp.1-14.

Krivy, M., Towards a Critique of Cybernetic Urbanism: The smart city and the society of control, Planning Theory, 17(1), (2018), pp. 8-30.

Sadowski, J \& Pasquale, F., "The Spectrum of Control: A Social Theory of the Smart City", First Monday, 20(7), (2015).

Sadowski, J., "Selling Smartness: Visions and Politics of the Smart City". PhD Dissertation, Human and Social Dimensions of Science and Technology, Arizona State University, (2016).

Sassen, S., "Urbanizing Technology", LSECities, (2012). https://lsecities.net/media/objects/ articles/urbanising-technology/en-gb/

Sennett, R., "No One Likes a City Thatss too Smart". The Guardian, December 4th, (2012). https://www.theguardian.com/com- 


\title{
The Smart City: From Modern Power to Smart Power
}

\author{
Abeer Allahham \\ Associate Professor, College of Design, Imam Abdulrahman Bin Faisal University, Saudi Arabia \\ drallahham@hotmail.com
}

Received 11/10/2020; accepted for publication 18/3/2021

\begin{abstract}
Despite its recent emergence, the concept of smart cities today is widely spread and accepted by many countries and governments. Yet, its definition and profound meaning remain hazy. Technology and digitalism, according to the main stream of smart cities, is the ideal "smart" solution for contemporary urban ills and the means to fulfil humanity's long standing dream of the Enlightenment. But is it true that the smart city is the ideal solution for the urban crisis cities face today? The smart city is primarily capitalist, however, adopting a new urban planning paradigm. Then, how can a capitalist approach address the urban ills that are essentially the production of its system? Can this paradigm be the illness and its cure at the same time? To answer this question, we must examine the deep level of the smart city's operating mechanisms and explore its dynamics in the management of the city and its people, with a special focus on the issues of authority and power. The paper attempts to investigate the concept of power in the production mechanisms of the smart city, its transformation from the modern to the smart concept, and the impact of such a change on the urban ills produced by capitalism and the modern power. Would such a shift in the concept of power address the urban city's problems, or would it create another type of crisis and other urban issues?
\end{abstract}

Key words: smart city, smart power, territoriality, capitalism, public-private. 